
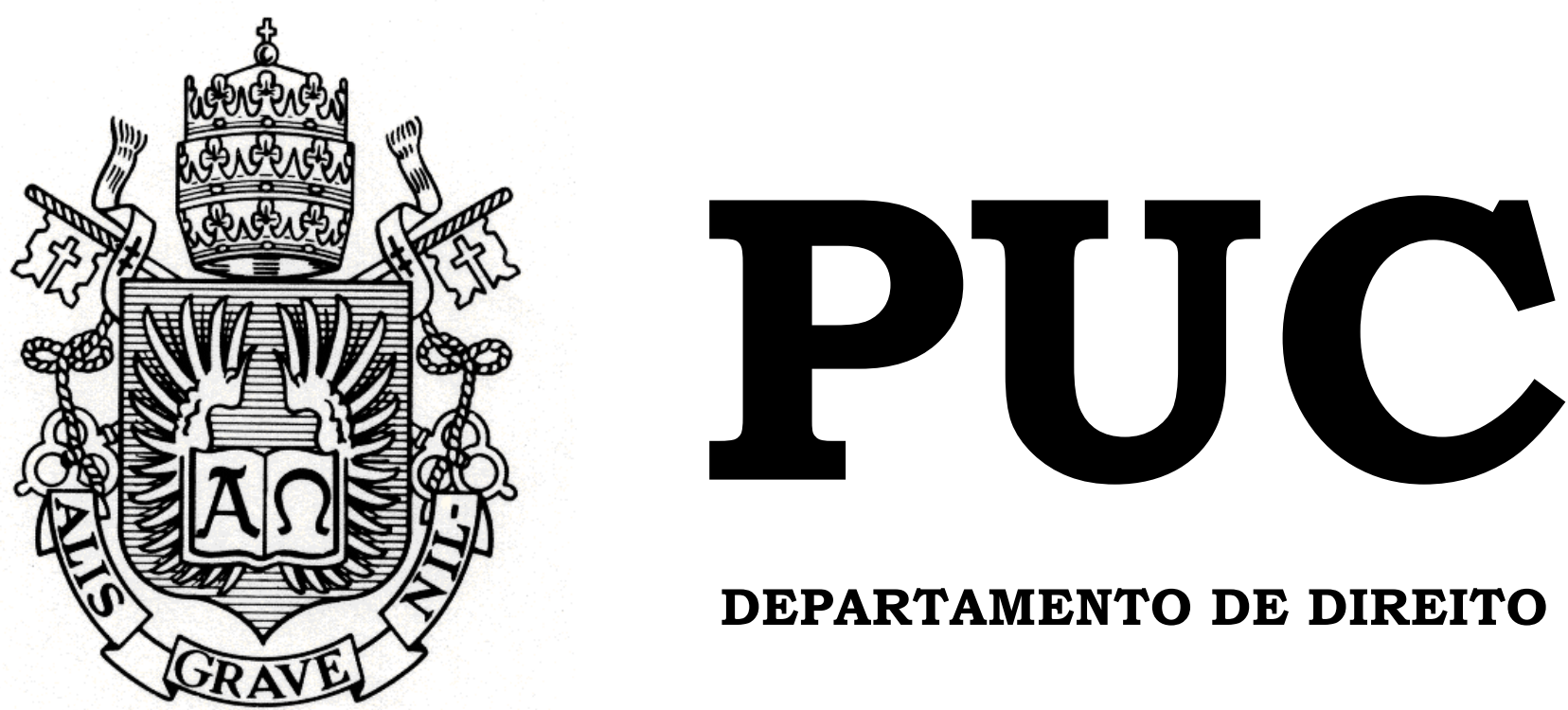

DEPARTAMENTO DE DIREITO

\title{
O PREJUÍZO COMO PREMISSA PARA O EXERCÍCIO DO DIREITO DE RECESSO
}

por

GIULIA DE MORAES RIBEIRO

ORIENTADOR: FRANCISCO ANTUNES MACIEL MÜSSNICH

2019.1

PONTIFÍCIA UNIVERSIDADE CATÓLICA DO RIO DE JANEIRO

RUA MARQUÊS DE SÃO VICENTE, 225 - CEP 22453-900

RIO DE JANEIRO - BRASIL 


\title{
O PREJUÍzo COMO PREMISSA PARA O EXERCÍCIO DO DIREITO DE RECESSO
}

\author{
por
}

\section{GIULIA DE MORAES RIBEIRO}

Monografia

apresentada

ao

Departamento de Direito da Pontifícia Universidade Católica do Rio de Janeiro (PUC-Rio) como requisito parcial para a obtenção do Título de Bacharel em Direito.

Orientador: Francisco Antunes Maciel Müssnich 


\section{RESUMO}

RIBEIRO, Giulia de Moraes. O prejuízo como premissa para o exercício do direito de recesso. Rio de Janeiro: 2019: 71 p. Monografia de final de curso. Departamento de Direito da Pontifícia Universidade Católica do Rio de Janeiro - PUC-Rio.

O trabalho aqui exposto pretende abordar os principais aspectos do direito de retirada nas sociedades por ações. Para tanto, inicia-se o estudo com uma análise acerca da origem do instituto e suas principais características na legislação brasileira. Após, será feito um breve exame do direito nas legislações italiana e americana, principalmente, tendo em vista sua influência na legislação brasileira, cujas hipóteses serão abordadas nos capítulos seguintes. Por fim, tendo em vista o caráter excepcional do instituto, será proposta uma reflexão acerca das consequências do exercício do direito de retirada nas companhias, motivo pelo qual o prejuízo demonstra-se como elemento essencial para a sua legitimação, por meio do qual assegura-se a preservação da companhia e a proteção aos acionistas dissidentes.

Palavras-Chave: Direito societário. Sociedades por ações. Direito de recesso. Direito comparado. Prejuízo. Princípio majoritário. Proteção às minorias. Acionista dissidente. 


\section{SUMÁRIO}

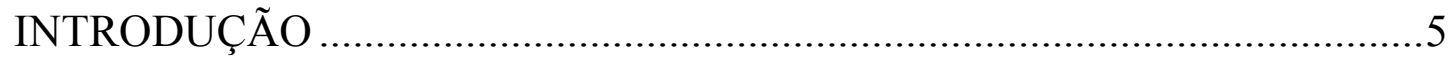

CAPÍTULO 1 - ORIGEM E DEFINIÇÃO ……….....................................

CAPÍTULO $2-\mathrm{O}$ DIREITO DE RECESSO NA LEGISLAÇÃO

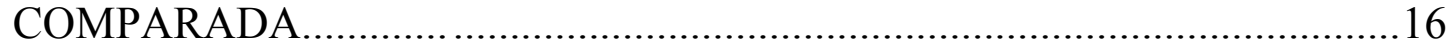

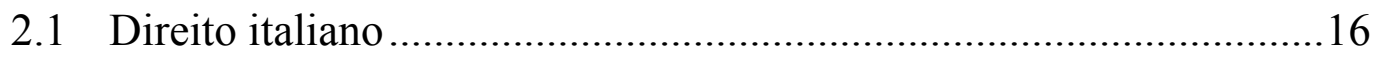

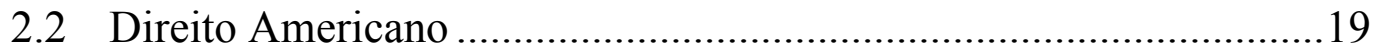

2.2.1 Delaware Corporation Law …………………................................20

2.2.2 Model Business Corporation Act ………………...........................24

2.3 Hipóteses de Recesso em Outros Direitos Estrangeiros .....................26

CAPÍTULO 3 - O DIREITO DE RECESSO NA LEGISLAÇÃO

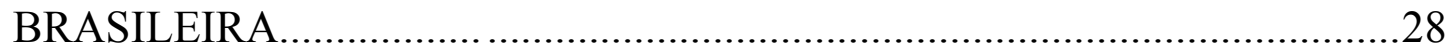

3.1 Requisitos para o Exercício do Direito de Retirada ...........................29

CAPÍTULO 4 - HIPÓTESES LEGAIS DE EXERCÍCIO DO DIREITO DE

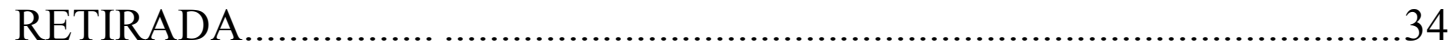

4.1 Criação de ações preferenciais ou aumento desproporcional ..............34

4.2 Alteração nos Direitos das Ações Preferenciais e criação de classe mais favorecida .37

4.3 Redução do dividendo obrigatório …………………………...............39

4.4 Fusão da companhia, ou sua incorporação em outra ...........................41

4.5 Participação em grupo de sociedades ..................................................42

4.6 Mudança do objeto social da companhia.............................................43

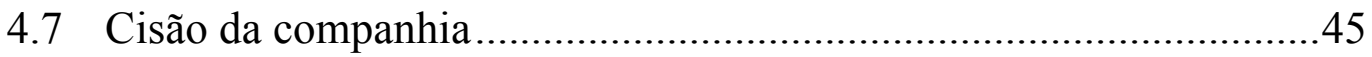

4.8 Transformação da companhia em outro tipo societário........................46

4.9 Não abertura do capital de sociedade resultante de operação ............47

4.10 Aquisição de controle por desapropriação...........................................48 
4.11 Incorporação de ações .49

4.12 Aquisição do controle de outra sociedade empresária.........................50

4.13 Inserção no estatuto de convenção de arbitragem ...............................51

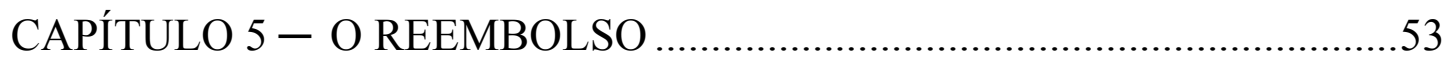

CAPÍTULO 6 - CONSEQUÊNCIAS DO EXERCÍCIO DO DIREITO DE

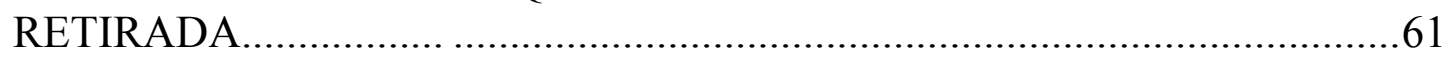

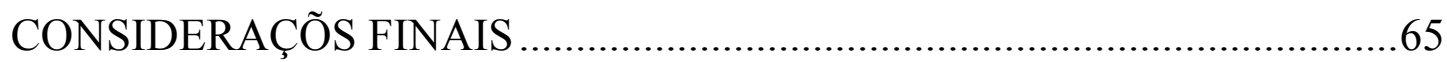

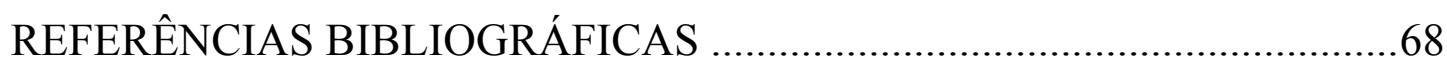




\section{INTRODUÇÃO}

O direito de retirada consiste no poder jurídico assegurado ao acionista de uma companhia de extinguir, por ato unilateral, nos casos previstos em lei, as relações de sócio que o vinculam à sociedade por ações. Ao exercer esse direito, o acionista aliena suas ações à companhia e dela recebe o valor de reembolso.

Tal instituto, também chamado de direito de recesso, surgiu para equilibrar a competência, reconhecida à assembleia geral, de modificar as bases essenciais do contrato da companhia. Reveste-se, portanto, de grande importância na medida em que se destina a conciliar o poder da maioria com os interesses dos acionistas, considerados individualmente.

Em regra, esse direito pode ser exercido nas hipóteses em que há:

i. Modificações nos direitos de participação dos acionistas: (a) criação de ações preferenciais; (b) aumento desproporcional de classe de ações preferenciais; (c) alteração de direitos das ações preferenciais; e (d) criação de nova classe de ações preferenciais mais favorecida;

ii. Modificações essenciais no estatuto social: (a) redução do dividendo obrigatório; (b) transformação da companhia; (c) mudança do objeto social; (d) participação em grupo de sociedades; (e) fusão ou incorporação em outra companhia; (f) cisão; (g) conversão em subsidiária integral mediante incorporação de ações; (h) sucessão de companhia aberta por companhia fechada; e (i) desapropriação do controle pelo poder público; e

iii. Aquisição de controle de companhia que constitua investimento relevante ou com pagamento de prêmio superior a 50\% do valor das ações.

Neste sentido, sua interpretação deve ser sempre norteada pela conciliação dos diversos interesses envolvidos, observado (i) o princípio 
majoritário e os interesses da companhia; e (ii) os direitos da minoria, considerados como os interesses particulares dos acionistas.

Este trabalho pretende abordar os principais aspectos relacionados à identificação de um elemento objetivo a ser considerado como premissa para a caracterização do direito de recesso: o prejuízo.

Para tanto, será feita uma breve análise histórica a respeito da origem do direito de retirada, através da qual serão abordadas as aplicações e alterações do instituto em legislações estrangeiras, e sua evolução no direito brasileiro.

Também serão analisadas as atuais hipóteses que permitem ao acionista dissidente de determinadas deliberações, tomadas em assembleia geral, de retirar-se da companhia mediante reembolso das ações de sua propriedade, bem como as possibilidades de cálculos sobre o valor da ação e premissas para o exercício do direito.

Este estudo revela-se importante na medida em que o direito de retirada, considerado instrumento fundamental na proteção das minorias nas sociedades por ações, também configura ferramenta que pode impactar negativamente as decisões relativas a operações alinhadas ao seu interesse social. Desta forma, torna-se imprescindível uma interpretação capaz de conciliar todos os interesses envolvidos a fim de se garantir um equilíbrio nas relações. 


\section{CAPÍTULO 1 - ORIGEM E DEFINIÇÃO}

Companhia, segundo o artigo $1^{\circ}$ da Lei 6.404/76 ("Lei das S.A." ou "Lei 6.404/76"), é uma pessoa jurídica de direito privado cujo capital é dividido em ações e cujos sócios ou acionistas possuem responsabilidade limitada ao preço de emissão das ações subscritas ou adquiridas.

Dos diferentes tipos societários existentes na legislação contemporânea, a sociedade por ações é a que melhor se destina à concentração de capitais.

Esta modalidade societária tem como característica principal a fungibilidade de membros, decorrente da grande circulação das partes representativas do seu capital, de forma que o capital aportado pelos participantes é, em regra, considerado mais relevante que a figura dos sócios.

A teoria jurídica das sociedades por ações sofreu, contudo, grandes modificações até se estabelecer na forma como é regida na atualidade.

No início de seu surgimento, a sociedade por ações era considerada um acordo de vontades. Os princípios norteadores das primeiras legislações a respeito do tema, portanto, foram basicamente aqueles que tratavam dos contratos.

A legislação francesa, por exemplo, nas primeiras décadas de vigência do Código de Comércio Francês de 1807, deixava clara a natureza contratual das sociedades por ações ao estabelecer que "as sociedades anônimas não podem ser feitas senão por contratos públicos"1.

Assim, a sociedade por ações nada mais era do que um contrato, não havendo espaço para que a assembleia geral pudesse alterar as bases essenciais

\footnotetext{
${ }^{1}$ LOUREIRO, Antonio José da Silva. Código Mercantil da França traduzido. Rio de Janeiro: Typ. Nacional, 1825. Disponível em: <http://www2.senado.leg.br/bdsf/handle/id/242784> Acesso em: 05 abr. 2019.
} 
da sociedade. Caso novos sócios desejassem fazer parte da sociedade, através de um aumento de capital, por exemplo, a alteração seria tratada como uma nova constituição parcial da sociedade.

Conforme explica a autora Anna Luiza Prisco Paraiso²:

O desenvolvimento do capitalismo, em consequência da revolução industrial, acarretou, todavia, transformações na estrutura jurídica da sociedade anônima. Em face da inadaptação da teoria dos contratos à moderna sociedade anônima, erigiu-se a teoria da instituição. Esta consistiu em conceber que a sociedade anônima era, como realmente é, uma pessoa moral, distinta da pessoa dos sócios, que não são vistos, acertadamente, como proprietários; são antes fornecedores de capital, investidores, especuladores do que proprietários. A sociedade deixa de ser concebida como um grupamento de pessoas para, progressivamente, ser vista como uma técnica jurídica de organização da empresa.

A partir desta mudança jurídica a respeito da concepção das sociedades por ações, percebe-se que sua natureza consiste em uma sociedade de capitais, uma vez que seu objetivo principal é agregá-los. Como decorrência desta característica, tem-se um grande número de sócios, ou acionistas, participando da companhia, o que a difere de outras formas de sociedades, nas quais os sócios constituem a figura principal na empresa, se reunindo em razão de um conhecimento recíproco.

Por tal razão, a regra da unanimidade nas deliberações costuma ser característica das sociedades de pessoas, sendo o funcionamento das sociedades por ações regido pelo princípio majoritário, através do qual é atribuído à vontade da maioria dos membros da coletividade o poder de decidir, vinculando toda a sociedade.

Justifica-se a adoção do princípio majoritário nas assembleias de acionistas por uma necessidade prática: exigir a unanimidade para aprovação nas deliberações assembleares, em companhias notoriamente conhecidas pelo

\footnotetext{
${ }^{2}$ PARAISO, Anna Luiza Prisco. O Direito de Retirada do Acionista Dissidente. Revista da CVM, Rio de Janeiro, v.4, n. 12, p.17-26, abr./jun.,1986, p. 18.
} 
grande número de participantes, tornaria inviável a consecução da atividade empresarial.

Neste sentido, o princípio majoritário passou a conferir, inicialmente, um aspecto democrático às sociedades por ações, com a ideia de que a maioria dos membros teria o poder de deliberar sobre o futuro da companhia. Ou seja, a vontade da maioria seria a que melhor traduzia a vontade social.

Com o tempo, a prática demonstrou que as deliberações não eram votadas de maneira democrática, de acordo com a vontade da maioria de seus membros, pois o voto não era contado em razão de seus titulares, e sim em razão das ações que detinham.

Como consequência, prevalece até os dias atuais o grupo - ou pessoa que possui a maior quantidade de ações com direito a voto nas deliberações, ou seja, ao menos, $50 \%$ mais $1 \%$ do total das ações com direito a voto de uma companhia, também chamado de controlador.

A este respeito, observa Alfredo Lamy Filho e José Luiz Bulhões Pedreira, ao citar D’Othée e Dominique Schmidt ${ }^{3}$ :

Em verdade - observa D’OTHÉE (1963, v.1, p. 363) - toda organização coletiva baseada sobre uma comunidade de interesses recíprocos está obrigada à adoção do princípio majoritário para a tomada de decisões.

Tal fato não consegue esconder que se trata de uma rara e, até mesmo, curiosa exceção ao grande princípio que domina o direito obrigacional, que é o livre consentimento das partes. Como salienta DOMINIQUE SCHMIDT (1970, p.21), a submissão dos indivíduos à lei da maioria é uma regra incomum do direito privado, um processo singular de gestão de bens alheios.

Para contrabalançar o poder da maioria nas deliberações assembleares, as legislações buscam assegurar aos acionistas, considerados individualmente,

\footnotetext{
${ }^{3}$ LAMY FILHO, Alfredo; PEDREIRA, José Luiz Bulhões. A Lei das S.A.: pareceres. 3. ed. Rio de Janeiro, Renovar, 1997, p. 229.
} 
alguns direitos chamados de essenciais, os quais nem o estatuto, nem a assembleia geral, podem privá-los (artigo 109 da Lei 6.404/76).

Neste contexto, o direito de retirada, também chamado de direito de recesso, surge dentre os direitos essenciais do acionista, com o propósito de manter o equilíbrio entre o poder atribuído à maioria de modificar as bases essenciais do contrato, e a preservação dos interesses dos minoritários. Assim, é conferido aos dissidentes o direito de se retirar da companhia, mediante o reembolso de suas ações, nos casos em que discordarem de determinadas deliberações tomadas pela maioria.

Sobre o assunto, discorre a professora Rachel Sztajn ${ }^{4}$ :

Recesso é o poder que a lei confere ao acionista dissidente de uma deliberação assemblear de, retirando-se da sociedade, subtrair-se à decisão majoritária. Complementa o princípio majoritário, permitindo que se implementem modificações organizacionais e estruturais desejáveis, deliberadas por maioria, sem que se faça necessário o constrangimento do dissidente que deveria subordinar-se a tal decisão.

No mesmo sentido, pondera Mauro Penteado ${ }^{5}$ :

Concebido como mecanismo destinado a preservar a manutenção da empresa e, ao mesmo tempo, possibilitar a retirada dos sócios discordantes das deliberações da assembleia, o direito de recesso, segundo o clássico Cesare Vivante, constitui remédio e freio aos abusos da maioria. ${ }^{6}$

Assim, o fundamento para a existência de tal direito decorre da possibilidade da maioria alterar significativamente as características daquela companhia originalmente investida, de modo a atribuir ao acionista minoritário

\footnotetext{
${ }^{4}$ SZTAJN, Rachel. O direito de recesso nas sociedades comerciais. Revista de Direito Mercantil, v.27, n. 71, p. $15,1988$.

${ }^{5}$ PENTEADO, Mauro Rodrigues. A Lei 7.958/89 e a Pretensa Modificação do Direito de Retirada dos Acionistas: uma discussão inócua. Revista de Direito Mercantil, Industrial, Econômico e Financeiro, São Paulo, n. 77, a. 29, jan./mar., 1990, p. 36.

${ }^{6}$ PENTEADO, Mauro. Trattato di Diritto Commerciale. 5. ed. Milão: Vallardi, 1923, p. 527.
} 
a faculdade de optar por não continuar a ser sócio de sociedade essencialmente diferente daquela cujas ações adquiriu.

A este respeito, acrescenta Anna Luiza Prisco Paraiso ${ }^{7}$ :

A exposição de motivos do Código de Comércio italiano explicava que a modificação que não afetasse a essência da sociedade e não agravasse as obrigações assumidas no contrato social era obrigatória para todos os sócios. Porém, quando a deliberação da assembleia se referisse a certas matérias, tidas como substanciais à estrutura original da sociedade, seria justo que aos sócios desconformes coubesse o direito de retirada da sociedade.

Depreende-se, assim, que as bases essenciais do contrato constituem o fundamento sobre o qual se baseia a decisão do investidor ao adquirir ou subscrever determinadas ações de certa companhia, de tal forma que a alteração desta estrutura modifica, de forma considerável, o investimento originalmente feito.

Embora tenha surgido como um meio de proteção aos acionistas minoritários, o direito de retirada também pode ser considerado como mecanismo de proteção à própria companhia.

Isto porque, além de proporcionar a viabilidade da atividade empresarial, através de deliberações majoritárias, também permite que a companhia possa se adaptar às circunstancias que se modificam ao longo do tempo, posto que, por vezes, o interesse social requer a alteração das bases essenciais do investimento para que a companhia possa sobreviver.

O direito de retirada opera, assim, como uma balança: busca, de um lado, possibilitar a transformação da sociedade e assegurar sua autonomia, e, por

\footnotetext{
${ }^{7}$ PARAISO, Anna Luiza Prisco. Op. Cit., p.19.
} 
outro, tutelar o interesse individual dos acionistas. Conforme leciona a professora Norma Parente ${ }^{8}$ :

Assim, a lei dá aos acionistas controladores poderes para aprovar determinadas medidas que afetam substancialmente o direito do acionista minoritário, mas nesses casos, para manter equilíbrio entre o poder assegurado à maioria dos acionistas para dirigir a sociedade e a minoria acionária, sujeita a seu arbítrio, a lei assegura ao acionista o direito individual e sagrado de se retirar da sociedade, mediante reembolso do valor de suas ações.

Com o passar do tempo, contudo, a aplicação de tal instituto demonstrou que, quando utilizado em companhias de médio e grande porte, a porcentagem de acionistas dissidentes pode ser tão alta a ponto de ameaçar sua sobrevivência após a descapitalização causada pelo pagamento do valor de reembolso. Neste sentido, é inegável a existência de um conflito de interesses entre o acionista, considerado individualmente, e o interesse geral da coletividade na criação, expansão, e fortalecimento das companhias.

A este respeito, explica Marcelo Lamy Rego9:

O conflito de interesses existe quando o interesse particular do sócio e o interesse social, este entendido como o interesse comum dos sócios, estão em situação contraposta ou antagônica. [...]

A expressão 'contraposta ou antagônica' é usada porque, caso exista a possibilidade de coexistência não danosa entre os dois interesses díspares, não há que se falar em conflito de interesses. $\mathrm{O}$ interesse distinto pode ser complementar, não excludente. $\mathrm{O}$ conflito nasce no momento em que os interesses são mutuamente excludentes (ainda que em parte), em que um necessariamente prejudica o outro, e em que o acionista se volta para fora do círculo societário, no qual está intimamente ligado a seus pares e aos destinos do empreendimento comum, para decidir o conteúdo do seu voto. Exerce, pois, seu direito de voto para satisfazer a esse interesse externo, estranho.

A existência do conflito ameaça o comando genérico, contido na LSA, de que o acionista deve exercer seu direito de voto no interesse da companhia, à medida que adiciona, ao processo de convencimento e de formação de vontade do acionista, elementos estranhos à comunhão. O resultado é que o voto, que deveria ser exercido com a finalidade de atender o interesse comum, é exercido para satisfazer interesse

\footnotetext{
${ }^{8}$ PARENTE, Norma Jonssen. O Direito de Recesso na Incorporação, Fusão ou Cisão de Sociedades. Revista de Direito Mercantil Industrial, Econômico e Financeiro, v. N.97, p. 68, 1995.

${ }^{9}$ LAMY REGO, Marcelo. Direito das companhias / coordenação Alfredo Lamy Filho, José Luiz Bulhões Pedreira. - 2. ed., atual. e ref. - Rio de Janeiro: Forense, 2017, p. 308.
} 
particular do acionista ou de terceiro. Desse exercício viciado do direito de voto configura-se o conflito proibido pela LSA.

Neste ponto, tendo em vista o interesse da coletividade na expansão e fortalecimento das companhias, concordamos com a opinião de Luis Eduardo Bulhões Pedreira, que considera o regime legal do direito de retirada cogente e taxativo $^{10}$. Ou seja, o direito de retirada não pode ser restringido nem ampliado, estando taxativamente previsto em lei as hipóteses que ensejam seu exercício.

\author{
Em sentido oposto, aduz Nelson Eizirik ${ }^{11}$ :
}

Prevalece na doutrina o entendimento de que somente podem ensejar o direito de retirada, com o reembolso do valor das ações, as hipóteses expressamente previstas na Lei das S.A. Trata-se de um 'mito' que não encontra qualquer amparo na lei societária. $\mathrm{Na}$ realidade, o que é vedado é a exclusão do direito de recesso por dispositivo estatutário ou por deliberação da assembleia geral, por tratar-se de um direito essencial do acionista (artigo 109, inciso V).

$[\ldots]$

Com efeito, o direito de recesso tem conteúdo puramente patrimonial. Não há qualquer razão para se negar validade à disposição estatutária que permita o 'desinvestimento', em certas hipóteses, mediante o reembolso do valor das ações.

Ao fundamentar a natureza taxativa do direito de retirada, explica Luis Eduardo Bulhões Pedreira ${ }^{12}$ :

Essa natureza decorre dos interesses que protege. O reembolso de ações pode implicar redução do capital social, instituto fundamental da companhia, de que dependem os direitos dos credores e a própria funcionalidade de sociedade que pode ter milhares e até milhões de acionistas em permanente substituição; e o direito de retirada excepciona o princípio de que o capital social não pode ser restituído aos acionistas em prejuízo dos credores sociais.

${ }^{10}$ PEDREIRA, L.E. Direito de retirada. In: LAMY FILHO, Alfredo; PEDREIRA, José Luiz Bulhões. Direito das companhias. 2. ed. Rio de Janeiro: Forense, 2017, p. 243.

${ }^{11}$ EIZIRIK, Nelson. A Lei das S/A Comentada. vol. II. arts. 121 a 188. São Paulo: Quartier Latin, 2011, p. 227.

${ }^{12}$ PEDREIRA, L.E. Op. Cit., p. 243. 
No mesmo sentido, defende a autora Anna Luiza Prisco Paraiso ${ }^{13}$ :

Contrariamente à tendência do direito comparado, o direito de retirada do acionista, em nossa legislação, apresenta-se de forma extremamente ampliada [...]

$\mathrm{Na}$ verdade, o direito de retirada deve ser encarado restritivamente, pois sem dúvida é um direito de caráter excepcional, capaz de provocar a descapitalização das sociedades, e particularmente difícil de adequar-se às sociedades anônimas abertas.

Resta evidente, portanto, que a natureza excepcional do direito de retirada não comporta sua ampliação por meio de cláusulas estatutárias, posto que a deliberação realizada para inclusão de hipóteses extensivas estaria em confronto com o interesse social da companhia, sendo deliberada pelos mesmos acionistas a serem beneficiados por ela, havendo, portanto, um claro conflito de interesses.

Além disso, a própria legislação esclarece tratar-se de direito taxativo, que não comporta ampliação estatutária, ao determinar, no artigo 109, inciso V da Lei das S.A., o direito do acionista de retirar-se da sociedade nos casos previstos em Lei.

É, portanto, direito cogente, taxativo e essencial do acionista, elencado no rol de direitos essenciais previsto no artigo 109 da Lei 6.404/76, que assim dispõe:

Art. 109. Nem o estatuto social nem a assembleia-geral poderão privar o acionista dos direitos de:

I - participar dos lucros sociais;

II - participar do acervo da companhia, em caso de liquidação;

III - fiscalizar, na forma prevista nesta Lei, a gestão dos negócios sociais;

IV - preferência para a subscrição de ações, partes beneficiárias conversíveis em ações, debêntures conversíveis em ações e bônus de subscrição, observado o disposto nos artigos 171 e 172;

V - retirar-se da sociedade nos casos previstos nesta Lei. (grifo nosso)

$[\ldots]$

Assim, depreende-se da norma em comento que o direito de retirada é direito do qual o acionista não pode ser privado, seja através de imposições de

\footnotetext{
${ }^{13}$ PARAISO, Anna Luiza Prisco. Op. Cit., p.26.
} 
restrição ou por meio da supressão pelo estatuto ou assembleia geral. É nula, portanto, a cláusula estatutária ou a deliberação assemblear que busca sua ampliação, bem como aquela que prevê sua limitação ou eliminação, impondo qualquer óbice ou onerosidade ao seu exercício. 


\title{
CAPÍTULO 2 - O DIREITO DE RECESSO NA LEGISLAÇÃO COMPARADA
}

\subsection{Direito italiano}

O direito de retirada tem sua origem no Código de Comércio Italiano de 1882, que assim dispôs, em seu art. $158^{14}$ :

\begin{abstract}
Qualora l'atto constitutivo o lo statuto non disponga altrimenti, è sempre necessaria la presenza di tanti socii che rappresentino i tre quarti del capitale sociale, ed il voto favorevole di tanti socii intervenuti che rappresentino almeno la metà del capitale medesimo, per deliberare:

$1^{\circ}$. Lo scioglimento anticipato della società;

$2^{\circ}$. La prorogazione della sua durata;

$3^{\circ}$. La fusione con altre società;

$4^{\circ}$. La riduzione del capitale sociale;

$5^{\circ}$. La reintegrazione o l'aumento del capitale stesso;

$6^{\circ}$. Il cambiamento dell'oggetto della società;

$7^{\circ}$. Ogni altra modificazione dell'atto costitutivo.

La maggioranza stessa è inoltre richiesta in tutti i casi specialmente designati dalla legge.

I socii dissenzienti dalle deliberazioni indicate nei numeri $3^{\circ}, 5^{\circ}$ e $6^{\circ}$ e dalla prorogazione della durata della società, se non è acconsentita nell'atto costitutivo, hanno diritto di recedere dalla società e di ottenere il rimborso delle loro quote od azioni in proporzione dell'attivo sociale secondo l'ultimo bilancio approvato.

Il recesso dev'essere dichiarato dagli intervenuti all'assemblea entro ventiquattro ore dalla chiusura di essa, e dagli altri socii entro un mese dalla pubblicazione della deliberazione nel giornale degli annuzi giudiziarii, sotto pena di decadenza. (grifo nosso)
\end{abstract}

Percebe-se, através da leitura do artigo, que o Código Comercial de 1882 já previa o princípio majoritário nas deliberações das companhias, permitindo à maioria acionária a modificação do estatuto social.

Em contrapartida, foi criado o direito de recesso ao acionista dissidente, conferindo a ele a possibilidade de se retirar da sociedade mediante o pagamento

\footnotetext{
${ }^{14}$ CODICE DI COMMERCIO DEL REGNO D’ITALIA. Roma: Regia Tipografia, 1882. Disponível em: <http://www.antropologiagiuridica.it/codecomit82.pdf> Acesso em: 05 abr, 2019.
} 
de reembolso do valor de suas ações, calculado de acordo com a respectiva proporção sobre o valor total do ativo da sociedade.

Neste sentido, a lei italiana previa o direito de retirada nos casos de fusão da sociedade com outra, reintegração do capital social ${ }^{15}$, aumento do capital social, mudança do objeto social e prorrogação do prazo da sociedade, quando não prevista no estatuto.

A este respeito, comenta Nelson Eizirik ${ }^{16}$ :

Inúmeras discussões surgiram sobre o recesso, no que se referia à sua natureza, se pública ou privada, à licitude das restrições estatutárias, ao prejuízo que poderia causar à companhia e ao fato de que os acionistas deveriam sempre suportar a deliberação majoritária, pois acreditava-se que alguns acionistas minoritários exerciam o recesso apenas para receber reembolso de suas ações. Assim, em 1942, com a entrada em vigor do Código Civil Italiano, houve a eliminação do direito de recesso em algumas hipóteses, sendo previsto, no artigo 2.437, apenas nos casos de mudança do objeto social, transformação de tipo societário ou na transferência da sede para o exterior.

Assim, com a Primeira Guerra Mundial a aplicação do direito de retirada foi suspensa na Itália, sendo mantido, no entanto, com a entrada em vigor do Código Civil Italiano de 1942. A nova lei, contudo, restringiu as hipóteses de aplicação aos casos de mudança do objeto social, transformação da sociedade e transferência da sede da companhia para o exterior ${ }^{17}$.

\footnotetext{
${ }^{15}$ Reintegração do capital social "é o caso de aumento do capital social após prévia redução de capital, para o qual os acionistas têm de fazer novo aporte de capital sem, contudo, receber em contrapartida ações da companhia". PEDREIRA, L.E. Op. Cit., p. 244.

${ }^{16}$ EIZIRIK, Nelson. Op. Cit., p. 200.

${ }^{17}$ O código civil italiano de 1942 prevê, em seu artigo 2.437: "Diritto di recesso.

I soci dissenzienti dalle deliberazioni riguardanti il cambiamento dell'oggetto o del tipo della società, o il trasferimento della sede sociale all'estero (2369) hanno diritto di recedere dalla società e di ottenere il rimborso delle proprie azioni, secondo il prezzo medio dell'ultimo semestre, se queste sono quotate in borsa, o, in caso contrario, in proporzione del patrimonio sociale risultante dal bilancio dell'ultimo esercizio.

La dichiarazione di recesso deve essere comunicata con raccomandata dai soci intervenuti all'assemblea non oltre tre giorni dalla chiusura di questa, e dai soci non intervenuti non oltre quindici giorni (2964) dalla data dell'iscrizione della deliberazione nel registro delle imprese (2188; att. 100).

E' nullo (1421 e seguenti) ogni patto che esclude il diritto di recesso o ne rende più gravoso l'esercizio."
} 
A este respeito, importa ressaltar, brevemente, que a legislação brasileira dispõe de maneira diversa acerca desta última hipótese, de modo que, por meio do Decreto $\mathrm{n}^{\circ}$ 2627, de 1940, condicionou a mudança de nacionalidade das companhias brasileiras ao consentimento unânime de seus acionistas. Neste ponto, estabelece o artigo 72 do referido dispositivo legal, cuja vigência foi assegurada pelo artigo 300 da Lei das S.A.: "A sociedade anônima ou companhia brasileira somente poderá mudar de nacionalidade mediante o consentimento unânime dos acionistas.”

Com a reforma do regime das sociedades por ações do Código Civil italiano, uma nova mudança ocorreu, ainda, em 2001, na qual houve uma flexibilização do instituto, de modo a ampliar o número de hipóteses que ensejam o direito de retirada. Admitiu-se, também, a restrição e ampliação das hipóteses de direito de recesso através do estatuto social nos casos em que a companhia é fechada.

Neste sentido, a reforma introduziu novas hipóteses legais de recesso inderrogáveis, discriminando-as daquelas passíveis de supressão ou modificação pelo estatuto. Assim, os casos que ensejam o direito de recesso, no direito italiano, passaram a ser divididos da seguinte forma:

Hipóteses que não podem ser suprimidas pelo estatuto:

(a) mudança substancial do objeto social da companhia;

(b) transformação da companhia;

(c) transferência da sede social da companhia para o exterior;

(d) cessação do estado de liquidação da companhia;

(e) supressão de hipótese de direito de retirada previsto no estatuto; 
(f) modificação dos critérios de determinação do valor de reembolso das ações; e

(g) modificação estatutária relativa a direito de voto ou direitos patrimoniais dos acionistas;

Hipóteses que podem ser suprimidas pelo estatuto:

(a) prorrogação do prazo de duração da sociedade; e

(b) mudança no regime de circulação das ações (direito de preferência, restrição à transferência de ações etc.); e hipóteses não previstas pela lei, que podem ser ampliadas pelo estatuto social de companhias fechadas.

A reforma inovou, também, em seu artigo $2.437-$ bis $^{18}$, no qual determina como causa de direito de recesso não apenas a deliberação assemblear, mas também o fato. Prevê, ainda, a possibilidade de recesso parcial, facultando ao acionista dissidente optar por graduar o montante investido na sociedade.

\subsection{Direito Americano}

Nos Estados Unidos da América, o direito de retirada - chamado de appraisal rights, right to dissent ou withdrawal right - constitui direito legalmente previsto nas legislações de diversos estados, através do qual os

\footnotetext{
${ }^{18}$ Dispõe o artigo 2.437-bis: Termini e modalità di esercizio.

Il diritto di recesso è esercitato mediante lettera raccomandata che deve essere spedita entro quindici giorni dall'iscrizione nel registro delle imprese della delibera che lo legittima, con l'indicazione delle generalità del socio recedente, del domicilio per le comunicazioni inerenti al procedimento, del numero e della categoria delle azioni per le quali il diritto di recesso viene esercitato. Se il fatto che legittima il recesso è diverso da una deliberazione, esso è esercitato entro trenta giorni dalla sua conoscenza da parte del socio.

Le azioni per le quali è esercitato il diritto di recesso non possono essere cedute e devono essere depositate presso la sede sociale.

Il recesso non può essere esercitato e, se già esercitato, è privo di efficacia, se, entro novanta giorni, la società revoca la delibera che lo legittima ovvero se è deliberato lo scioglimento della società.

CODICE CIVILE ITALIANO. Disponível em:

$<$ http://www.jus.unitn.it/cardozo/obiter_dictum/codciv/Lib5.htm> Acesso em: 15 abr. 2019.
} 
acionistas dissidentes de determinadas deliberações tomadas pela assembleia geral possuem a faculdade de se retirar da companhia mediante o reembolso do valor justo (fair value) de sua participação na sociedade.

Nos Estados Unidos, adota-se o federalismo centrífugo, no qual o Estado cria entes federativos autônomos e independentes, sendo estes competentes para legislar sobre as mais diversas matérias, entre elas, direito empresarial corporate law.

Por tal razão, as deliberações que ensejam o direito de recesso variam de acordo com a legislação de cada estado. No entanto, praticamente todos os estados americanos consideram corporate consolidations e mergers como operações que ensejam o direito do acionista de retirar-se da companhia ${ }^{19}$.

Não obstante, as principais fontes de corporate law para as companhias norte-americanas são a Delaware Corporation Law e o Model Business Corporation Act, razão pela qual serão melhor abordadas a seguir, no que tange às suas disposições acerca do direito de retirada.

\subsubsection{Delaware Corporation Law}

Dispõe o $\$ 262$ da Delaware Corpoation Law que qualquer acionista que não tenha votado a favor da deliberação acerca de corporate consolidations ou merger, ou consentido por escrito, terá direito a uma avaliação pelo judiciário

\footnotetext{
19 “Appraisal Rights. Also referred to as dissenters' rights. A statutory remedy available in many states to stockholders who object to certain extraordinary actions taken by the corporation (such as mergers). This remedy typically allows dissenting stockholders to require the corporation to repurchase their stock at a price equivalent to its fair market value immediately before the extraordinary corporate action. The nature of the extraordinary corporate action that triggers this right differs in every state. For example, some states make appraisal rights available in an asset purchase transaction or when a company makes certain amendments to its certificate of incorporation, while others do not. However, almost all states consider corporate consolidations and mergers as transactions triggering appraisal rights."

PRACTICAL LAW. Glossary. Thomson Reuters. Disponível em: $<$ https://uk.practicallaw.thomsonreuters.com/4-3823234 ?transitionType $=$ Default $\&$ contextData $=($ sc.Default $) \&$ firstPage $=$ true $\&$ comp $=$ pluk $\& b h c p=1>$. Acesso em: 15 abr. 2019.
} 
para que possam aferir o valor justo das ações de propriedade daquele acionista $^{20}$.

A este respeito, discorre Luis Eduardo Bulhões Pedreira ${ }^{21}$ :

Em regra, a Delaware Corporation Law (lei do Estado onde historicamente as companhias norte-americanas, em sua maior parte, são constituídas) dá direito de retirada nos casos de incorporação, para os acionistas da incorporada, e de fusão de companhias, para os de ambas as companhias; e, ainda, faculta ao estatuto social dar direito de retirada nos casos de alteração do estatuto social e de alienação, permuta ou arrendamento, pela companhia, de substancialmente todos os seus ativos. Qualquer acionista, titular de qualquer classe ou espécie de ação, nesses casos, terá direito de retirada, desde que a matéria de deliberação em questão dependa do voto dos acionistas, que o acionista tenha direito de votar essa matéria, e que o acionista não tenha exercido seu direito de voto em favor da modificação proposta, ou com esta consentido por escrito.

Assim, conforme dispõe a alínea d, do artigo em comento, quando houver proposta de deliberação da assembleia geral para aprovação de operação de fusão ou aquisição envolvendo a companhia, esta deverá notificar seus acionistas com, pelo menos, 20 dias de antecedência da data da deliberação, a respeito da faculdade de exercer o direito de retirada. O acionista que desejar exercer tal direito deverá entregar à companhia, antes da votação da deliberação, notificação por escrito, comunicando que pretende exercê-lo, bem como a quantidade de ações em relação à qual pretende exercer o direito.

Comunicada a intenção de exercer o direito de recesso, caberá ao poder judiciário fazer uma avaliação a fim de determinar o valor justo das ações daquele acionista dissidente.

Neste ponto, comenta Anna Luiza Prisco Paraiso ${ }^{22}$ :

O direito de retirada do acionista nos EUA é mais comumente denominado de appraisal right ou appraisal remedy ${ }^{36}$, ou seja, trata-se do direito de os acionistas dissentirem de certas deliberações da assembleia de pedir o pagamento de suas ações, cujo valor, em geral, é fornecido pelo Poder Judiciário. Isto ocorre porque as leis dos Estados não

\footnotetext{
${ }^{20}$ Tradução livre do parágrafo 262. STATE OF DELAWARE. The Official Website of the First State. Disponível em: <http://delcode.delaware.gov/title8/c001/sc09/index.shtml.> Acesso em: 15 abr. 2019.

${ }^{21}$ PEDREIRA, L. E. Op. Cit., p. 245.

${ }^{22}$ PARAISO, Anna Luiza Prisco. Op. Cit., p. 21.
} 
determinam o modo pelo qual as sociedades devem avaliar as ações. As legislações apenas prescrevem que deve ser pago um valor justo, ou simplesmente um valor ${ }^{37}$.

Assim, a característica básica do direito de retirada nos EUA é a fixação, pelos tribunais, do valor do reembolso ${ }^{38}$, com o que os acionistas quase nunca concordam

$[\ldots]$

As legislações dos Estados membros não prescrevem uma forma de calcular o valor das ações dos dissidentes. Em geral, a avaliação dessas baseia-se no preço de mercado no dia da deliberação que ensejou o exercício do direito de dissentir ${ }^{41}$. Os tribunais, por sua vez, opinam sobre a dificuldade de fixação de um padrão único para a avaliação ${ }^{42}$.

Quando as ações são cotadas em Bolsa ou no mercado de balcão, o Judiciário tem decidido estabelecer um preço correspondente ao valor de um desses mercados da ação, em um dia considerado relevante ${ }^{43}$. Por outro lado, quando a sociedade é fechada, não havendo mercado para suas ações, o reembolso pode ser calculado em função do princípio contábil da continuidade (Going Concern Value), ou baseado na avaliação de um hipotético balanço de liquidação.

Uma peculiaridade do direito de recesso norte-americano é que, segundo a Delaware Corporation Law, o acionista que decide exercer o direito tem a faculdade de, dentro de 60 dias da data da deliberação, reconsiderar o exercício do direito. Neste caso, ao contrário do direito brasileiro, no qual é facultado à companhia o direito de retratação, de modo a desistir da operação, é facultado ao acionista desistir de retirar-se da companhia, mediante o reembolso.

Além disso, é importante ressaltar que, segundo esta legislação, o acionista perde o direito de votar e receber dividendos no momento em que exerce o direito de retirada, e assim permanece até que ocorra eventual reconsideração de sua decisão.

Para que haja o direito ao exercício do direito de retirada é necessário que não haja liquidez e dispersão das suas ações. Assim, regra geral, não há direito de recesso nas companhias abertas e nas companhias fechadas cujas ações sejam detidas por mais de 2.000 acionistas.

Discorre Luis Eduardo Bulhões Pedreira a respeito ${ }^{23}$ :

Essa supressão (ou limitação) do direito de retirada nas companhias abertas ou nas fechadas com alta dispersão de ações é conhecida no direito norte-americano como market-out exception, e se assemelha à atual exceção ao direito de retirada nas

\footnotetext{
${ }^{23}$ PEDREIRA, L. E. Op. Cit., p. 246.
} 
companhias abertas introduzida pela LSA (v. §96), com a diferença de que nos EUA a presunção de liquidez e dispersão é absoluta, enquanto no direito brasileiro ela é relativa e depende da análise de cada caso específico ante os critérios de liquidez e dispersão definidos na LSA. Contudo, a market-out exception só se aplica nos casos em que o acionista recebe em contrapartida da deliberação ações (ou certificados de ações) de companhia participante do negócio de reorganização ou outra companhia aberta. Assim, por exemplo, se em decorrência de uma operação de incorporação de uma companhia em outra os acionistas da incorporada receberem, em substituição às suas ações, dinheiro ou qualquer outra forma de compensação, a market-out exception ficará afastada, e os acionistas da companhia aberta poderão exercer o direito de retirada - é o que se conhece como a exception to the market-out exception.

Assim, a market-out exception abrange os casos em que as ações envolvidas na operação societária são líquidas e dispersas, de modo que há uma presunção absoluta de que seu preço de mercado reflete seu valor justo. Para que a exceção seja aplicada, no entanto, é necessário que os acionistas prejudicados (que, em tese, possuiriam o direito de recesso) recebam, em contrapartida à operação, ações de companhia envolvida na reestruturação societária. Caso contrário, a exceção será afastada e os acionistas da companhia poderão exercer o direito de retirada, ainda que suas ações possuam liquidez e dispersão no mercado $^{24}$.

\footnotetext{
24 “The so-called market-out exception precludes appraisal where the target's stock trades in a highly liquid market. In other words, appraisal is normally available to shareholders except, as the rationale goes, where the M\&A target's stock trades in such a liquid, highly efficient market that its stock price naturally reflects its fair value, and any M\&A transaction offering a premium to that market price thus provides shareholders even greater, above-market value that would render an appraisal challenge superfluous.

Delaware's appraisal statute incorporates the market-out exception, precluding appraisal rights where the target's stock is either "(i) listed on a national securities exchange or (ii) held of record by more than 2,000 holders." DGCL $\S 262(\mathrm{~b})(1)$. But the Delaware statute doesn't stop there, and this is where it parts ways with many other states: it then carves out from the market-out exception circumstances where the target's stock is being acquired for cash, in whole or in part. As a result of this exception to the exception, Delaware's market-out exception has far fewer teeth than do those of jurisdictions that adopted the market-out exception outright, without exception. Thus, based on the theory underlying the statute, and notwithstanding the purported liquidity and efficiency of the stock markets in which most public M\&A targets are traded, Delaware allows stockholders of its corporations to assert appraisal rights rather than assume that the market price inevitably captures the maximum value of their shares." The market out exception delawares unique twist on a commonly used anti appraisal device. Appraisal rights litigation. Disponível em: <https://www.appraisalrightslitigation.com/2016/04/13/the-marketout-exception-delawares-unique-twist-on-a-commonly-used-anti-appraisal-device/> Acesso em: 15 abr. 2019.
} 


\title{
2.2.2 Model Business Corporation Act
}

\author{
O direito de retirada norte-americano também é previsto pelo Model \\ Business Corporation Act (MBCA), em seu capítulo 13, no qual é possível \\ perceber que o instituto possui, em grande parte, as mesmas características \\ daquele regulado pela Delaware Corporation Law.
}

Difere, contudo, no que tange às hipóteses que ensejam o direito de recesso, uma vez que o MBCA aumentou, consideravelmente, as causas de recesso $^{25}$. Neste sentido, listamos, a seguir, algumas hipóteses previstas no MBCA que ensejam o direito de retirada:

(a) Fusão de companhias;

(b) Permuta de ações;

(c) Venda ou troca de ativos em montante expressivo, fora do curso normal dos negócios;

\footnotetext{
${ }^{25}$ Prevê o capítulo 13, seção 02, do Model Business Corporation Act: $§$ 13.02. Right to Appraisal. (a) A shareholder is entitled to appraisal rights, and to obtain pay- ment of the fair value of that shareholder's shares, in the event of any of the following corporate actions: (1) consummation of a merger to which the corporation is a party (i) if shareholder approval is required for the merger by $\S 11.04$ and the shareholder is entitled to vote on the merger, except that appraisal rights shall not be available to any shareholder of the corporation with respect to shares of any class or series that remain outstanding after consummation of the merger, or (ii) if the corporation is a subsidiary and the merger is governed by $\S 11.05$; (2) consummation of a share exchange to which the corpora- tion is a party as the corporation whose shares will be ac- quired if the shareholder is entitled to vote on the exchange, except that appraisal rights shall not be available to any share- holder of the corporation with respect to any class or series of shares of the corporation that is not exchanged; (3) consummation of a disposition of assets pursuant to $\S 12.02$ if the shareholder is entitled to vote on the disposition; (4) an amendment of the articles of incorporation with respect to a class or series of shares that reduces the number of shares of a class or series owned by the shareholder to a fraction of a share if the corporation has the obligation or right to repur- chase the fractional share so created; (5) any other amendment to the articles of incorporation, merger, share exchange or disposition of assets to the extent provided by the articles of incorporation, bylaws or a resolu- tion of the board of directors; (6) consummation of a domestication if the shareholder does not receive shares in the foreign corporation resulting from the domestication that have terms as favorable to the share- holder in all material respects, and represent at least the same percentage interest of the total voting rights of the outstand- ing shares of the corporation, as the shares held by the share- holder before the domestication; (7) consummation of a conversion of the corporation to non- profit status pursuant to subchapter 9C; or (8) consummation of a conversion of the corporation to an un- incorporated entity pursuant to subchapter $9 \mathrm{E}$.
} 
(d) Transferência do bloco de controle;

(e) Transformação da companhia em entidade sem fins lucrativos; e

(f) Alterações substanciais que prejudiquem os direitos dos acionistas, modificando as condições de resgate, extinguindo o direito de preferência e limitando o direito de voto.

Assim, é importante ressaltar que, no que tange à hipótese de transferência do bloco de controle, o MBCA entende que a market-out exception não é aplicada aos casos em que, pela incorporação, fusão ou permuta, as ações ou ativos da companhia venham a ser adquiridos (i) por titular de mais de $20 \%$ das ações com direito a voto da companhia; (ii) por pessoa com poder para eleger 25\% ou mais dos membros do Conselho de Administração; ou (iii) por diretores executivos da companhia em condições não estendidas aos demais acionistas.

Além disso, outra peculiaridade de tal legislação é a previsão que dispõe sobre a possibilidade do estatuto social limitar, ou até mesmo suprimir, o exercício do direito de recesso dos titulares de ações preferenciais. Prevê, também, que a companhia será responsável por determinar o valor de reembolso, de modo que, se o acionista discordar do valor fixado, poderá se negar a recebêlo e submeter a disputa ao Poder Judiciário, que determinará o valor devido.

Por fim, o MBCA não adota a exceção da market-out exception, de modo que não há direito de retirada nas companhias abertas e nas fechadas com alta dispersão de ações, ainda que o acionista receba apenas dinheiro como consequência da operação societária, perdendo a qualidade de sócio em função da deliberação assemblear. 


\subsection{Hipóteses de Recesso em Outros Direitos Estrangeiros}

A legislação chilena prevê o direito do acionista retirar-se da companhia nas seguintes situações:

(a) Fusão ou incorporação da companhia em outra;

(b) Outorga de garantias, pela companhia, em favor de terceiros, em obrigações cujo valor seja superior a $50 \%$ dos ativos da companhia;

(c) Transformação da companhia;

(d) Reintegração total ou parcial do capital social;

(e) Alienação de mais de $50 \%$ dos ativos da companhia;

(f) Constatação e reparação de erros formais em documentos de organização da companhia, inclusive o estatuto social e suas alterações; e

(g) Criação de ações preferenciais e alteração de seus direitos.

Já no direito argentino, podemos observar um aumento considerável do número de hipóteses que ensejam o exercício do direito. Segundo a lei, há direito de retirada nos casos de:

(a) Transformação da companhia;

(b) Mudança do objeto social essencial da companhia;

(c) Transferência da sede para o exterior;

(d) Fechamento de capital ou extinção da cotação das ações em Bolsa, ou retirada de oferta pública;

(e) Declaração de nulidade da dissolução da companhia;

(f) Fusão, incorporação ou cisão da companhia;

(g) Prorrogação do prazo de duração da companhia; e 
(h) Aumento de capital, caso o acionista tenha que fazer novo aporte, exceto nos casos em que há previsão estatutária do capital autorizado, e o aumento não excede a cinco vezes o valor do capital social da companhia.

A lei argentina também prevê a possibilidade de previsão estatutária ampliando o rol de hipóteses que ensejam o direito de retirada, bem como o direito de retratação, também previsto no direito brasileiro, através do qual a companhia pode reconsiderar a decisão que ensejou o exercício do direito de retirada. 


\section{CAPÍTULO 3 - O DIREITO DE RECESSO NA LEGISLAÇÃO BRASILEIRA}

O direito de recesso na sociedade por ações foi previsto, pela primeira vez, no Decreto $n^{\circ} 21.536 / 1932$, que determinava, no artigo $9^{\circ}$ :

Art. $9^{\circ}$ Aprovada a proposta a que se refere o artigo anterior, os acionistas preferenciais dissidentes, que fizerem parte de qualquer das classes prejudicadas, terão direito ao reembolso do valor das suas ações, se o reclamarem à diretoria dentro de trinta dias, contados da publicação da ata da assembleia geral.

Assim, era facultado aos acionistas dissidentes de deliberação que alterava as preferências e vantagens das quais eram titulares, ou criava ações com outras preferências, o direito ao reembolso de suas ações.

Ao longo dos anos, o instituto sofreu diversas alterações, ora sendo ampliado, ora reduzido, até se consolidar na redação vigente, prevista na lei 6.404/76, com modificações introduzidas pela lei $n^{\circ} 10.303 / 2001$.

Conforme explicado anteriormente, recesso consiste em um poder conferido, pelo legislador, ao acionista dissidente de determinadas deliberações assembleares, através do qual lhe é facultado retirar-se da sociedade mediante o reembolso do valor de suas ações.

Ao dispor sobre o assunto a lei procura, por meio de tal instituto, proteger os acionistas minoritários contra determinadas modificações substanciais na estrutura da companhia ou redução de direitos assegurados através de suas ações, de modo que não seja forçado a permanecer sócio de uma companhia essencialmente diversa da qual adquiriu ações.

Neste sentido, é importante ter em mente que não é qualquer deliberação assemblear que gera o direito de recesso do acionista dissidente. Se assim o fosse, a companhia seria obrigada a reembolsar acionistas dissidentes a cada 
assembleia a ser realizada, o que, mais uma vez, tornaria inviável a consecução da atividade empresarial.

Isto porque, muitas vezes, a alteração faz-se necessária para a manutenção das atividades da companhia e a constante necessidade de pagamento do reembolso tornaria tais mudanças demasiadamente onerosas, impedindo sua realização e, consequentemente, a continuação da atividade empresária.

Por tal razão, o legislador estabeleceu um rol taxativo de alterações societárias que, em tese, geram o direito de retirada do acionista dissidente.

\subsection{Requisitos para o Exercício do Direito de Retirada}

Atualmente, o direito de retirada encontra seu fundamento no artigo 137 da Lei das S.A., que assim dispõe:

Art. 137. A aprovação das matérias previstas nos incisos I a VI e IX do art. 136 dá ao acionista dissidente o direito de retirar-se da companhia, mediante reembolso do valor das suas ações (art. 45), observadas as seguintes normas:

I - nos casos dos incisos I e II do art. 136, somente terá direito de retirada o titular de ações de espécie ou classe prejudicadas;

II - nos casos dos incisos IV e V do art. 136, não terá direito de retirada o titular de ação de espécie ou classe que tenha liquidez e dispersão no mercado, considerando-se haver:

a) liquidez, quando a espécie ou classe de ação, ou certificado que a represente, integre índice geral representativo de carteira de valores mobiliários admitido à negociação no mercado de valores mobiliários, no Brasil ou no exterior, definido pela Comissão de Valores Mobiliários; e

b) dispersão, quando o acionista controlador, a sociedade controladora ou outras sociedades sob seu controle detiverem menos da metade da espécie ou classe de ação; III - no caso do inciso IX do art. 136, somente haverá direito de retirada se a cisão implicar:

a) mudança do objeto social, salvo quando o patrimônio cindido for vertido para sociedade cuja atividade preponderante coincida com a decorrente do objeto social da sociedade cindida;

b) redução do dividendo obrigatório; ou

c) participação em grupo de sociedades;

IV - o reembolso da ação deve ser reclamado à companhia no prazo de 30 (trinta) dias contado da publicação da ata da assembleia-geral;

V - o prazo para o dissidente de deliberação de assembleia especial (art. 136, § 1o) será contado da publicação da respectiva ata; 
VI - o pagamento do reembolso somente poderá ser exigido após a observância do disposto no $\S 30$ e, se for o caso, da ratificação da deliberação pela assembleia-geral. $\S 1^{\circ} \mathrm{O}$ acionista dissidente de deliberação da assembleia, inclusive o titular de ações preferenciais sem direito de voto, poderá exercer o direito de reembolso das ações de que, comprovadamente, era titular na data da primeira publicação do edital de convocação da assembleia, ou na data da comunicação do fato relevante objeto da deliberação, se anterior.

$\S 20 \mathrm{O}$ direito de reembolso poderá ser exercido no prazo previsto nos incisos IV ou V do caput deste artigo, conforme o caso, ainda que o titular das ações tenha se abstido de votar contra a deliberação ou não tenha comparecido à assembleia.

$\S 30$ Nos 10 (dez) dias subsequentes ao término do prazo de que tratam os incisos IV e V do caput deste artigo, conforme o caso, contado da publicação da ata da assembleiageral ou da assembleia especial que ratificar a deliberação, é facultado aos órgãos da administração convocar a assembleia-geral para ratificar ou reconsiderar a deliberação, se entenderem que o pagamento do preço do reembolso das ações aos acionistas dissidentes que exerceram o direito de retirada porá em risco a estabilidade financeira da empresa.

$\S 4^{\circ}$ Decairá do direito de retirada o acionista que não o exercer no prazo fixado.

$\mathrm{O}$ artigo em comento determina, assim, que o acionista que dissentir no momento da deliberação de certas matérias elencadas, no artigo 136 da mesma lei poderá retirar-se da sociedade mediante o exercício do direito de recesso, através do qual receberá reembolso relativo ao valor das ações de que era titular.

Neste ponto, importa ressaltar que o artigo 136 da Lei 6.404/76 não esgota as hipóteses de direito de retirada. Conforme se verá adiante, outros artigos do mesmo diploma legal também preveem casos que ensejam o exercício de tal direito $^{26}$.

Do disposto no artigo 137 supracitado, é possível perceber dois requisitos necessários para o exercício do direito de recesso: (i) ser titular de ações da companhia na data da primeira publicação do edital de convocação da assembleia, ou na data da comunicação do fato relevante objeto da deliberação, quando anterior; e (ii) ser dissidente de deliberação tomada em assembleia geral que enseja o exercício do direito de recesso.

\footnotetext{
${ }^{26}$ Neste sentido, é possível verificar hipóteses que ensejam o direito de recesso, direta ou indiretamente, em outras normas, tais como os artigos 221, 223, 236, 252, 256 e 264, que serão analisados adiante.
} 
O primeiro requisito tem como fim evitar que ocorram abusos no exercício do direito de retirada. A redação antiga determinava que o acionista tinha direito ao exercício do recesso com relação às ações de que era titular na data da assembleia geral, de modo que muitas pessoas, tendo conhecimento de que as deliberações a serem votadas ensejavam o direito de retirada, adquiriam ações da companhia antes da assembleia com o único propósito de exercer o direito de retirada, causando graves prejuízos à companhia.

Neste sentido, a atual redação busca evitar tais abusos, de maneira que, caso uma pessoa adquira ações após a data estipulada no $\S 1^{\circ}$ do artigo em referência, não poderá exercer o direito de retirada.

Quanto ao requisito da dissidência, explica Nelson Eizirik ${ }^{27}$ :

O conceito de acionista dissidente abrange aquele que comparece à assembleia e vota contra a deliberação, o que esteve ausente, o que compareceu ao conclave e se absteve de votar, bem como o acionista que não tem direito de voto. Nesse sentido, (i) o $\S 1^{\circ}$ estabelece que o acionista dissidente de deliberação, inclusive o titular de ações preferenciais sem direito de voto, poderá exercer o direito de reembolso de suas ações; e (ii) o $\S 2^{\circ}$ determina que o direito de reembolso pode ser exercido no prazo previsto nos incisos IV ou V do caput, conforme o caso, ainda que o titular das ações tenha se abstido de votar contra a deliberação ou não tenha comparecido à assembleia.

A lei estabelece, ainda, no art. 137, II da Lei 6.404/76, uma importante limitação ao exercício do direito de recesso ao determinar que, nos casos previstos nos incisos IV e V do artigo 136, não haverá direito de retirada quando o acionista for titular de ação de espécie ou classe que tenha liquidez e dispersão no mercado. Ou seja, a liquidez e dispersão são requisitos cumulativos para que $\mathrm{o}$ acionista não possa exercer o direito.

\footnotetext{
${ }^{27}$ EIZIRIK, Nelson. A Lei das S/A Comentada. Volume II - Arts. 121 a 188. São Paulo: Quartier Latin, 2011, p. 206.
} 
Em sentido oposto, entende o professor Francisco Müssnich que os requisitos de liquidez e dispersão seriam alternativos, nos seguintes termos ${ }^{28}$ :

Outra questão, de igual relevo, se encontra abordada pelo inciso II do art. 137, alterado pela Lei $\mathrm{n}^{\mathrm{o}}$ 10.303/01 que dispõe que, na fusão da companhia em grupo de sociedades, o direito de recesso não poderá ser exercido se forem preenchidos, pelo menos, um dos requisitos essenciais, a saber: primeiro, que se trate de espécie ou classe de ações - ou certificado que a represente - de uma companhia (obviamente aberta) que integre índice geral representativo de carteira de ações admitido à negociação no mercado de valores mobiliários, no Brasil ou no exterior, definido pela CVM; e, em segundo lugar, também apenas aplicável às companhias abertas, que seja classe ou espécie de ações das quais se encontram em circulação no mercado mais da metade do total dessa classe ou espécie, entendendo-se, nesse caso, por ações em circulação, as referidas ações menos as de propriedade do acionista controlador, da sociedade controladora ou de outras sociedades sob controle do controlador, o que significa dizer que, em princípio, as ações em tesouraria não serão computadas para a verificação do preenchimento dessa condição (ao contrário do que está previsto na Instrução CVM n ${ }^{\circ}$ 229, de 16 de janeiro de 1995). (grifo nosso)

Não obstante, o fundamento desta limitação é simples: havendo a possibilidade de o acionista alienar suas ações no mercado, não há razão para forçar a companhia a reembolsar tal participação, posto que os recursos a serem despendidos no reembolso poderiam ser utilizados para financiar atividades importantes para a companhia.

A respeito, explica Modesto Carvalhosa ${ }^{29}$ :

Assim, a Lei n. 9.457/97 excluiu o direito de recesso nas hipóteses em que as ações da companhia possuíssem elevados níveis de liquidez ou quando apresentassem índices expressivos de dispersão no mercado.

A justificativa para a exclusão pela Lei n. 9.457/97 do direito de retirada nessas hipóteses reside no fato de que, tendo as ações liquidez, bastaria ao acionista dissidente vender suas ações no mercado e retirar-se da companhia, não havendo necessidade de obrigar esta última a reembolsá-lo.

Dessa forma, entendeu o legislador de 1997 que quando as ações possuem status de plena negociabilidade, consoante presunção legal, não havia por que exigir a

\footnotetext{
${ }^{28}$ MÜSSNICH, Francisco Antunes Maciel. Reflexões sobre o direito de recesso na lei das sociedades por ações. Reforma da Lei das Sociedades Anônimas, inovações e questões controvertidas da Lei $\mathrm{n}^{\circ}$ 10.303, de 31.10.2001. Editora Forense, 2a Edição. Rio de Janeiro: 2002, p. 298.

${ }^{29}$ CARVAlHOSA, Modesto. A nova Lei das sociedades anônimas/ Modesto Carvalhosa e Nelson Eizirik. - São Paulo: Saraiva, 2002, p. 268.
} 
descapitalização da companhia, com todos os riscos patrimoniais que poderiam advir do pagamento aos acionistas dissidentes do valor do reembolso de suas ações.

Neste sentido, a lei estabelece, nas alíneas "a" e "b", do inciso II, do artigo 137, os seguintes critérios para se avaliar a liquidez e dispersão da ação:

a) liquidez, quando a espécie ou classe de ação, ou certificado que a represente, integre índice geral representativo de carteira de valores mobiliários admitido à negociação no mercado de valores mobiliários, no Brasil ou no exterior, definido pela Comissão de Valores Mobiliários; e

b) dispersão, quando o acionista controlador, a sociedade controladora ou outras sociedades sob seu controle detiverem menos da metade da espécie ou classe de ação;

Neste ponto, faz-se aqui uma crítica à redação da alínea $b$ supramencionada, posto que, na prática, nem sempre haverá dispersão quando os minoritários detiverem $50 \%$ ou mais da espécie ou classe de ação. Isto porque pode haver casos em que os minoritários detenham menos de 50\%, mas, ainda assim, sejam muitos e tenham grande poder de negociação no mercado aberto, bem como são possíveis situações em que minoritários detenham mais de 50\%, mas sejam poucos e, por isso, não possuam capacidade negocial.

Não obstante a discussão acima, a crítica que aqui se faz relaciona-se ao texto do inciso II do art. 137 da Lei das S.A., que determina que apenas nos casos dos incisos IV e V do art. 136 o conceito de liquidez e dispersão será aplicável como impeditivo para o exercício do direito de recesso.

Isto porque, tendo em vista a capacidade de tal direito influenciar a viabilidade das atividades da empresa, entendemos que a restrição em comento deveria ser aplicável aos demais casos que ensejam direito de retirada, pois a impossibilidade de o acionista alienar suas ações a terceiros deveria ser pressuposto básico para o exercício do direito.

Feitas as considerações necessárias, analisaremos, a seguir, as hipóteses legalmente previstas que ensejam o direito de retirada do acionista dissidente de deliberação assemblear. 


\section{CAPÍTULO 4- HIPÓTESES LEGAIS DE EXERCÍ́CIO DO DIREITO DE RETIRADA}

\subsection{Criação de ações preferenciais ou aumento desproporcional}

A primeira hipótese a dar ensejo ao exercício do direito de retirada é a criação de ações preferenciais ou o aumento desproporcional de classe de ações preferenciais existentes, salvo se já previstos ou autorizados pelo estatuto (art. 136, inciso I, da Lei das S.A.).

Neste cenário, o direito de retirada pretende proteger o interesse dos titulares de ações ordinárias de participar dos lucros sociais e, em eventual caso de liquidação, do acervo da companhia.

Isto porque as ações preferenciais conferem direitos e vantagens especiais a seus titulares em relação aos demais, de modo que sua criação sujeita os direitos dos titulares de ações ordinárias aos titulares de ações preferenciais.

Conforme esclarece Renata Brandão Moritz ${ }^{30}$ :

Aqui são duas as hipóteses. A primeira refere-se à criação de ações preferenciais. Esta alteração estatutária interfere diretamente nos direitos patrimoniais dos acionistas portadores de ações ordinárias, pois implica em conferir aos portadores de novas ações vantagens pecuniárias tais como prioridade na distribuição dos dividendos, prioridade no reembolso do capital, ou a cumulação de ambas as vantagens (conforme o art. 17). Portanto elas conferem aos seus portadores maiores direitos econômicos.

$[\ldots]$

A segunda hipótese apresentada no inc. I do art. 136 trata do aumento das ações preferenciais sem guardar proporção com as demais. Quando é decidido o aumento do número de preferenciais, tanto os acionistas dissidentes portadores de ações ordinárias, como os portadores de preferenciais já existentes são atingidos, podendo exercer o direito de se retirar.

[...]

Quando a companhia possui capital formado por ações ordinárias e ações preferenciais de mais de uma classe e seus acionistas deliberam aumentar uma das classes, em total

\footnotetext{
${ }^{30}$ MORITZ, Renata Brandão. As Hipóteses de Recesso da Lei das Sociedades Anônimas. Revista dos Tribunais, São Paulo, a. 86, v. 736, fev., 1997, p. 73.
} 
desproporção quanto às outras ações já existentes (tanto as ordinárias, como as preferenciais de outras classes), não só os acionistas dissidentes portadores das ações ordinárias, mas os portadores das ações preferenciais de outras classes também teriam o direito de se retirar da sociedade. Isto porque tal alteração aumentaria os privilégios patrimoniais dos portadores das ações da classe aumentada, em detrimento das ações ordinárias dos primeiros e das preferências dos segundos.

No que tange à segunda hipótese apresentada no inciso I do artigo 136, qual seja, o aumento das ações preferenciais sem guardar proporção com as demais, é importante destacar que, não obstante a opinião acima exposta da autora Renata Brandão Moritz, e de outros autores como Luis Eduardo Bulhões Pedreira, há controvérsias na doutrina acerca dos titulares do direito de recesso em tal situação.

Isto porque o direito de recesso possui um caráter excepcional, de modo que as hipóteses autorizadoras de tal direito devem ser interpretadas restritivamente. Dessa forma, tendo em vista que o artigo dispõe expressamente sobre a desproporção entre ações preferenciais, poderia ensejar a interpretação no sentido de que somente os titulares de ações preferenciais prejudicadas através do aumento seriam titulares de tal direito.

Sobre o assunto, discorre o professor Nelson Eizirik $^{31}$ :

O novo texto legal, inequivocamente, excluiu o exercício do direito de recesso em decorrência da emissão de novas ações preferenciais da única classe existente, sem manter a proporção com as ações ordinárias. O objetivo dessa alteração foi o de tornar mais clara a regra que já decorria da redação original, qual seja, de que o recesso somente subsiste em face da alteração da proporção entre as diversas classes de ações preferenciais.

Não obstante, ao ponderar sobre o assunto, fundamenta Modesto Carvalhosa acerca das razões pelas quais a referida alteração enseja o direito de retirada igualmente aos titulares de ações ordinárias ${ }^{32}$ :

\footnotetext{
${ }^{31}$ EIZIRIK, Nelson. Op. Cit., p. 210.

${ }^{32}$ CARVALHOSA, Modesto. Comentários à Lei de Sociedades Anônimas. vol. II. arts. 75 a 137. 5. ed. São Paulo: Saraiva, 2011, p. 1.076.
} 
A regra de que o direito cabe a qualquer acionista não deve, no entanto, ser entendida como absoluta. Há o pressuposto de que o interesse do acionista foi atingido.

$[\ldots]$

Se, no entanto, a modificação dos direitos de uma espécie, forma ou classe repercute em outra espécie, classe ou forma, os titulares destas ações atingidas podem exercer o direito. Será o caso de criação de preferenciais, aumento desproporcional ou modificação (favorável) dos direitos referentes a elas, do que decorrerá prejuízo aos interesses patrimoniais dos titulares de ações ordinárias.

Acerca da criação de ações preferenciais, acrescenta Luis Eduardo Bulhões Pedreira ${ }^{33}$ :

Se a companhia é constituída com estatuto que já prevê a criação de ações preferenciais, a deliberação de criá-las não dá direito de retirada. Esse direito existe, entretanto, se a Assembleia Geral da companhia, sem previsão estatutária de ações preferenciais, delibera modificar o estatuto autorizando sua emissão no futuro. Neste caso, o procedimento de criação das ações preferenciais é dividido em duas etapas autorização no estatuto e posterior emissão das ações - e o direito de retirada pode ser exercido no momento da modificação estatutária, pois quando as ações vierem a ser emitidas não haverá direito de retirada porque já estarão autorizadas no estatuto. (grifo nosso)

Sendo assim, tendo em vista que os efeitos da criação ou do aumento de ações preferenciais variam de acordo com as circunstâncias concretas, o legislador adotou, no artigo 137, inciso I, redação genérica, por meio da qual assegura o direito de retirada apenas aos acionistas titulares de ações que sejam efetivamente prejudicadas em cada deliberação.

Neste sentido, aos acionistas preferenciais é assegurado a possibilidade de se retirar da companhia somente quando incluídos em classe subordinada à classe criada ou aumentada; e quando titulares de ações da classe aumentada, porque um maior número de ações passa a ter as mesmas vantagens das ações existentes.

Dessa forma, o prejuízo mencionado pelo legislador não se refere a um dano, posto que tal termo pressupõe, de acordo com o ordenamento jurídico

\footnotetext{
${ }^{33}$ PEDREIRA, L. E. Op. Cit., p. 252.
} 
brasileiro, um ato ilícito que afeta o patrimônio material e moral de alguém, conforme dispõe o artigo 186 do Código Civil: "Aquele que, por ação ou omissão voluntária, negligência ou imprudência, violar direito e causar dano a outrem, ainda que exclusivamente moral, comete ato ilícito."

Ao contrário, as alterações deliberadas pela assembleia geral ensejadoras do direito de retirada constituem atos lícitos, previstos expressamente em lei, de modo que não violam quaisquer direitos dos acionistas.

Isto posto, decorre da interpretação do artigo que o prejuízo referido na lei refere-se a uma possível diminuição de direitos de participação do acionista. Ou seja, o prejuízo ocorre quando o seu interesse patrimonial é alcançado pelas alterações deliberadas.

\subsection{Alteração nos Direitos das Ações Preferenciais e criação de classe mais favorecida}

A partir da leitura dos artigos 137, inciso I combinado com o artigo 136, inciso II encontra-se a segunda hipótese que dá ensejo ao direito ora estudado: a alteração das preferências, vantagens e condições de resgate ou amortização de classe de ações preferenciais, ou criação de classe mais favorecida, confere direito de retirada ao titular de ação prejudicada.

A partir da emissão de ações preferenciais, cria-se, para o titular destas, direito adquirido relacionado às preferências, vantagens ou condições de resgate ou amortização daquelas ações. Diante disso, tais atributos somente poderão ser modificados através de deliberação da assembleia geral, na qual mais da metade de cada classe de ações prejudicadas deverá aprovar previamente tais alterações. Por conseguinte, os dissidentes da deliberação da assembleia especial possuem, como proteção, o direito de retirada, posto que haverá uma mudança fundamental nas características de suas ações. 
Assim, quando da alteração das preferências resultar redução de vantagens ou direitos, aos acionistas da classe prejudicada será conferido o direito de retirar-se da sociedade. Por outro lado, caso o resultado da alteração seja o aumento de direitos ou vantagens de certa classe, será conferido direito de recesso aos acionistas das classes prejudicadas, que se encontram em posição subordinada às classes favorecidas.

Neste ponto, aduz Renata Brandão Moritz ${ }^{34}$ :

Se a alteração for para diminuir as preferências de determinada classe, então apenas os acionistas dissidentes titulares desta classe serão prejudicados e apenas estes poderão se retirar. No Parecer da Superintendência Jurídica 60/78 a CVM confirma tal entendimento, esclarecendo que 'a alteração para menos das preferências de uma classe de ações preferenciais em nada afeta aos interesses das demais classes de preferenciais, beneficiando, ao contrário, a situação das ações ordinárias' e concluindo que só os titulares das ações prejudicadas poderão exercer o direito de recesso.

Se a alteração determinar um aumento das vantagens ou preferências de uma classe, então os acionistas dissidentes portadores das ações de outras classes e das ordinárias podem se retirar.

Assim, conquanto a posição da referida autora no que tange à alteração nos direitos das ações preferenciais, pondera Luis Eduardo Bulhões Pedreira ${ }^{35}$ :

O direito de retirada visa proteger os titulares de ações preferenciais contra deliberações que modifiquem, na essência, as características das suas ações, uma vez que nem toda deliberação que causa diminuição de fluxo financeiro aos titulares daquelas ações promove modificação da cláusula que regula os seus direitos, suas vantagens, ou preferências.

Quanto à criação de nova classe de ações mais favorecida, esta hipótese ensejará o direito de retirada aos titulares de ações que serão prejudicadas com tal criação, ou seja, aos titulares de ações preferenciais, quando as ações a serem criadas forem mais favorecidas em relação a estes, ou apenas aos acionistas

\footnotetext{
${ }^{34}$ MORITZ, Renata Brandão. Op. Cit., p. 75.

${ }^{35}$ PEDREIRA, L. E. Op. Cit., p. 254.
} 
ordinários, quando ações a serem criadas forem menos favorecidas com relação às preferenciais existentes.

Neste ponto, novamente, há controvérsias na doutrina acerca dos titulares de ações ordinárias terem direito a retirar-se da companhia neste caso. No entanto, o fundamento para o exercício encontra-se no fato de que a criação de ações preferenciais sempre pressupõe prejuízo ao acionista ordinário, porque subordinado às ações preferenciais.

\subsection{Redução do dividendo obrigatório}

Conforme determina o art. 136, III e art. 137 da Lei 6.404/76, a redução do dividendo obrigatório confere, aos acionistas dissidentes da deliberação que a aprova, a possibilidade de exercer o direito de retirada.

A este respeito, ensina Fran Martins ${ }^{36}$ :

Procurando defender os interesses dos acionistas, muitas vezes ludibriados por atos da administração, a lei brasileira estipulou (art. 202) um dividendo obrigatório a ser distribuído aos acionistas, fixando, inclusive, o modo de apuração do valor do mesmo. Assim, constitui dividendo a ser distribuído anualmente aos acionistas pelo menos uma 'parcela dos lucros estabelecida no estatuto, ou, se esse for omisso, metade do lucro líquido do exercício', acrescido ou diminuído da quota destinada à constituição da reserva legal, da importância destinada à formação de reservas para contingências, a reversão dessas reservas formadas em exercício anteriores e os lucros a realizar transferidos para a respectiva reserva. Se, por acaso, o estatuto social estabelecer o dividendo obrigatório, poderá fixá-lo como porcentagem do lucro ou do capital social, ou mesmo por outro critério, desde que esse critério não seja regulado 'com precisão e minúcias', e não sujeite os acionistas minoritários ao arbítrio dos órgãos de administração ou da maioria (art. 202, §1 $1^{\circ}$ ).

$[\ldots]$

Fixado o dividendo obrigatório, por qualquer dos critérios estabelecidos na lei, se a assembleia geral extraordinária resolver alterá-lo, o acionista dissidente da deliberação terá o direito de recesso, na forma do art. 137 combinado com o n. IV do art. 136 da lei.

\footnotetext{
${ }^{36}$ MARTINS, Fran. O direito de recesso na lei brasileira das sociedades anônimas. Revista Forense, v. 1, jul./set., 1904, p. 47.
} 
É importante notar que o dispositivo mencionado pelo supracitado autor, foi modificado pela Lei $\mathrm{n}^{\circ}$ 9.457/97, através da qual houve a substituição da palavra "alteração" por "redução" do dividendo obrigatório. Acerca do tema, esclarece Francisco Müssnich que a alteração da redação foi importante "uma vez que não faria sentido que o aumento do dividendo obrigatório pudesse ensejar seu exercício, já que inexistiria qualquer prejuízo para os acionistas, que estariam recebendo um acréscimo de dividendos"37.

O dividendo obrigatório consiste em uma espécie de proteção aos acionistas minoritários, conferida pela Lei das S.A., a fim de garantir que os acionistas participem do lucro da companhia, assegurando o retorno do investimento realizado. Segundo o art. 202 da Lei 6.404/76, o dividendo obrigatório será estipulado no estatuto social ou, se omisso, será referente à metade do lucro líquido do exercício, observadas as normas impostas pelos incisos do referido dispositivo.

Neste sentido, a deliberação que aprova a redução do dividendo obrigatório diminui os direitos dos acionistas, alterando, portanto, uma base essencial do investimento feito, motivo pelo qual enseja o exercício do direito de retirada.

É importante notar que, neste caso, a lei não solicita a demonstração de prejuízo do acionista porque a configuração da hipótese caracteriza, por si só, um dano patrimonial à sua participação nos lucros da companhia.

\footnotetext{
${ }^{37}$ MÜSSNICH, Francisco Antunes Maciel. Reflexões sobre o direito de recesso na lei das sociedades por ações: reforma da lei das sociedades anônimas, inovações e questões controvertidas da Lei $\mathrm{n}^{\circ}$ 10.303, de 31.10.2001. 2. ed. Rio de Janeiro: Forense, 2002, p. 295.
} 


\subsection{Fusão da companhia, ou sua incorporação em outra}

Segundo dispõe o art. 136, inciso IV e art. 137 da Lei das S.A., a fusão da companhia, ou sua incorporação em outra, conferem hipóteses de direito de recesso.

Neste ponto, importa notar que tais hipóteses, assim como a que veremos adiante (participação em grupo de sociedades), haviam sido eliminadas da legislação brasileira como hipóteses ensejadoras do direito de recesso. Foram restauradas, contudo, de forma limitada, pela Lei $n^{\circ}$ 9.457/97.

Acerca deste resgate legislativo, explica José Edwaldo Tavares Borba ${ }^{38}$ :

A restauração do direito de recesso nas incorporações, fusões e participação em grupo de sociedades apresenta, contudo, caráter marcadamente circunscrito às companhias fechadas e a algumas companhias abertas que não se enquadram nas situações indicativas de liquidez e dispersão, fixadas pelo legislador no inciso II, alíneas "a" e "b", do art. 137, com a redação que lhe foi atribuída pela Lei $n^{\circ}$ 9.457/97, depois reformulada pela Lei $\mathrm{n}^{\mathrm{o}} 10.303 / 01$.

Isto porque a fusão e a incorporação provocam alterações substanciais nas bases essenciais da companhia, pois têm por efeito a extinção de uma ou ambas as companhias: na fusão, ambas as companhias são extintas mediante a criação de uma nova sociedade; já na incorporação, apenas a incorporada deixa de existir, tornando-se parte da incorporadora.

Neste sentido, o direito de retirada busca assegurar ao acionista uma alternativa para que não seja obrigado a ingressar em companhia diversa daquela na qual investiu originariamente.

Desta forma, é conferido aos acionistas das companhias fundidas e aos acionistas da companhia incorporada o direito de escolher entre receber ações da nova companhia, ou da incorporadora, ou exercer o direito de retirada. No

\footnotetext{
${ }^{38}$ BORBA, José Edwaldo Tavares. Direito societário. 13.ed. Rio de Janeiro: Renovar, 2012, p. 405.
} 
último caso, no entanto, é importante ressaltar que a lei condiciona o exercício do direito de recesso a dois elementos cumulativos: ausência de liquidez e dispersão no mercado.

Caso as ações sejam dotadas de uma ou ambas características, caberá ao acionista, querendo se desvincular da companhia, alienar a terceiro, pois não existe justificativa para obrigar a companhia a reembolsar o valor, despendendo de recursos que poderiam ser investidos na atividade empresarial, quando existe a opção, para o acionista, de ser desvinculado de forma alternativa, mas também onerosa.

Conforme dispõe o art. 230 da mesma lei, o prazo para exercício do direito de retirada, nestes casos, será contado a partir da publicação da ata que aprovar o protocolo ou justificação, mas o pagamento do preço de reembolso somente será devido no caso de efetivação da operação.

\subsection{Participação em grupo de sociedades}

A deliberação da assembleia geral que aprova a participação da companhia em grupo de sociedades possibilita, ao acionista dissidente da deliberação, o exercício do direito de retirada, desde que as ações de que seja titular não sejam líquidas e não estejam dispersas no mercado, conforme se depreende da leitura do art. 136, inciso V e art. 137, inciso II.

A este respeito, ensina Luis Eduardo Bulhões Pedreira ${ }^{39}$ :

A constituição de grupo de sociedades (de direito, e não de fato) justifica o direito de retirada porque a companhia perde sua autonomia: as sociedades que integram o grupo mantêm suas personalidades jurídicas, mas o interesse de cada uma pode ser subordinado ao do grupo, de outra sociedade, e da sociedade de comando do grupo. Dessa subordinação de interesses podem ocorrer situações que, embora em benefício do grupo como um todo, sejam desfavoráveis à sociedade que dele participe, inclusive

\footnotetext{
${ }^{39}$ PEDREIRA, L. E. Op. Cit., p. 255.
} 
pela diminuição de seus lucros para aumento dos de outra ou outras sociedades do grupo (art. 276).

Ou seja, a participação em grupo de sociedades pode implicar alteração dos objetivos da sociedade, pois esta passa a se subordinar a um interesse maior, qual seja, do grupo. Desta forma, qualquer acionista dissidente das sociedades envolvidas, passa a ser titular do direito de recesso.

\subsection{Mudança do objeto social da companhia}

O Decreto-lei $\mathrm{n}^{\circ}$ 2.627/1940 conferia, aos acionistas dissidentes, o direito de retirar-se da companhia quando da deliberação da assembleia geral resultasse mudança do objeto essencial da companhia.

Neste ponto, a Lei 6.404/76 suprimiu a palavra "essencial” do artigo, não alterando, contudo, o fundamento da norma, uma vez que a mesma lei dispõe, a respeito do conceito de objeto social:

Art. $2^{\circ}$ Pode ser objeto da companhia qualquer empresa de fim lucrativo, não contrário à lei, à ordem pública e aos bons costumes.

[...]

$\S 2^{\circ} \mathrm{O}$ estatuto social definirá o objeto de modo preciso e completo.

$\S 3^{\circ}$ A companhia pode ter por objeto participar de outras sociedades; ainda que não prevista no estatuto, a participação é facultada como meio de realizar o objeto social, ou para beneficiar-se de incentivos fiscais.

Neste sentido, não é qualquer mudança no objeto social da empresa que conferirá o direito de retirada aos acionistas dissidentes, mas tão somente alterações que resultem em substituição das bases essenciais do negócio da companhia.

A este respeito, importa ressaltar o disposto no $\S 3^{\circ}$, do artigo $2^{\circ}$, ora em comento: a companhia pode participar de outras sociedades como forma de realizar seu objeto social. 
Acerca do assunto, explica Alfredo Lamy Filho, ao citar Giancarlo Fré e Galgano $^{40}$ :

Mudança ('cambiamento') significa algo mais que modificação, pois deve tratar-se de uma deliberação em seguida à qual o objeto social resulte diverso do que era originariamente, para poder-se afirmar que mudou (È cambiato). (1961, p.603).

Ou, como diz Galgano:

O direito de recesso assiste aos dissidentes em caso de mudança do objeto social, e não em todos os casos de modificação do mesmo objeto: só ocorre, para que o acionista possa exercitar o recesso da sociedade, quando a maioria haja deliberado substituir o objeto social originário por um novo objeto em tudo diverso, de forma a modificar radicalmente as condições de risco em presença das quais o acionista havia aderido à sociedade (da produção automobilística se passa, por exemplo, à indústria têxtil). Modificação secundária do objeto social, como extensão a setores acessórios da produção, ou como a redução dos setores originários de atuação, não dão lugar ao direito de recesso. (1984, p. 324).

A alteração do objeto social pode implicar em modificação da empresa e do mercado onde ela atua, de modo que toda a análise de investimento feita pelo acionista, ao adquirir as ações daquela companhia, poderá ser alterada por completo, afetando o cálculo da viabilidade de retorno do investimento feito.

Assim, há uma quebra da expectativa do acionista acerca do mercado em que ele investiu, e a alteração da atividade pode ter reflexos significativos na capacidade da companhia ter lucros, ou até mesmo nos riscos a que será exposta, motivo pelo qual se justifica o exercício do direito de recesso em tais hipóteses.

No entanto, a partir da leitura dos arts. 136, VI e 137 da Lei das S.A. é possível perceber que a lei não impõe qualquer tipo de limitação ao exercício de tal direito, tal como a existência de um prejuízo ou ausência de liquidez e dispersão no mercado, conferindo uma hipótese extremamente onerosa à companhia, tema que será melhor abordado adiante.

\footnotetext{
${ }^{40}$ LAMY FILHO, Alfredo; PEDREIRA, José Luiz Bulhões. A Lei das S.A.: pressupostos, elaboração, aplicação. Rio de Janeiro: Renovar, 1996, p.324.
} 


\subsection{Cisão da companhia}

A deliberação da assembleia geral que aprovar a cisão da companhia somente enseja o direito de retirada se a cisão implicar: (i) mudança do objeto social, salvo quando o patrimônio for vertido para sociedade cuja atividade preponderante coincida com a decorrente do objeto social da sociedade cindida; (ii) redução do dividendo obrigatório; ou (iii) a participação em grupo de sociedades (art. 136, inciso IX combinado com o art. 137, III, ambos da Lei 6.404/76).

A cisão é a operação pela qual a companhia transfere parcelas do seu patrimônio para uma ou mais sociedades, constituídas para esse fim ou já existentes, extinguindo-se a companhia cindida, se houver versão de todo o seu patrimônio, ou dividindo-se o seu capital, se parcial a versão (art. 229 da Lei $6.404 / 76)$.

No tocante à hipótese em referência, explica José Edwaldo Tavares Borba $^{41}$ :

A cisão, que também fora excluída do direito de recesso pela Lei $\mathrm{n}^{\circ} 7.958 / 89$, assim se mantivera sob a égide da Lei $\mathrm{n}^{0}$ 9.457/97. O pressuposto dessa exclusão era o entendimento de que a cisão significava a mera divisão da sociedade, com a manutenção dos mesmos acionistas nas várias empresas resultantes da reestruturação, situação que, em linha de princípio, não acarretaria qualquer dano real ou potencial aos interesses dos acionistas. Entretanto, uma das hipóteses de cisão é a da cisão com incorporação, tal como previsto no art. 229 da Lei $n^{0}$ 6.404/76, ao definir o instituto. Nesse caso, cabe observar que os efeitos da cisão são semelhantes aos da incorporação, devendo-se, consequentemente, aplicar as normas sobre o direito de recesso, inclusive por força do disposto no $\S 3^{\circ}$ do art. 229 , que manda aplicar à cisão com incorporação as disposições sobre incorporação.

Com a Lei ${ }^{\circ} 10.303 / 01$, a cisão voltou a ser incluída entre as hipóteses de recesso, mas apenas (art. 137, III) quando o recesso já ocorreria em virtude de outros incisos do art. 136 (mudança de objeto, redução do dividendo obrigatório, participação em grupo de sociedades), situações em que a doutrina, a partir da interpretação sistemática da lei, já considerava aplicável o recesso.

${ }^{41}$ BORBA, José Edwaldo Tavares. Op. Cit., p. 404. 
Assim, havendo cisão total de uma companhia, será assegurado o direito de retirada apenas se a sociedade decorrente da operação não possuir o mesmo objeto social da companhia que foi extinta. Caso haja uma sociedade com atividade coincidente, não haverá direito de retirada, pois será considerado mera divisão do objeto social.

Caso haja uma cisão com incorporação, operação na qual parcelas do patrimônio da companhia cindida são transferidas para sociedades já existentes, deverão ser observadas as normas referentes ao direito de retirada na incorporação, pois há uma maior diversidade de efeitos na operação.

Uma vez configurada hipótese de direito de recesso prevista no inciso III do art. 137 da Lei das S.A., o acionista da companhia cindida terá a possibilidade de exercer o direito sobre todas as suas ações. O recesso é exercido sobre todas as ações potencialmente atingidas.

\subsection{Transformação da companhia em outro tipo societário}

Transformação é a operação pela qual a sociedade passa, independentemente de dissolução e liquidação, de um tipo societário para outro (art. 220 da Lei das S.A.). Neste caso, não há substituição de uma pessoa jurídica por outra, ou seja, não há sucessão de patrimônio, o que ocorre é apenas uma modificação no regime jurídico.

Conforme previsto no art. 221 da Lei das S.A., a transformação exige o consentimento unânime dos sócios ou acionistas, salvo se prevista no estatuto ou no contrato social, caso em que o sócio dissidente terá o direito de retirar-se da sociedade. Ou seja, haverá direito de recesso apenas quando prevista no estatuto ou contrato social regra diferente da unanimidade sobre a deliberação da transformação, seja qual for a maioria estabelecida. 
A este respeito, vale ressaltar que o parágrafo único do mencionado artigo prevê que os sócios podem renunciar, no contrato social, ao direito de retirada no caso de transformação em companhia. Essa hipótese é aplicável somente aos casos em que uma sociedade limitada é transformada em sociedade por ações, de modo que não colide com o disposto no art. 109 da Lei das S.A. porque este rege acionistas de companhias, não sócios de limitadas. A referida lei proíbe a renúncia em estatutos sociais, mas não proíbe nos contratos sociais das limitadas.

Neste sentido, cabe destacar o disposto no artigo 1.113 do Código Civil (Lei 10.406/2002), acerca da transformação das sociedades por ele regidas:

Art. 1.113. O ato de transformação independe de dissolução ou liquidação da sociedade, e obedecerá aos preceitos reguladores da constituição e inscrição próprios do tipo em que vai converter-se.

Assim, o dispositivo em comento autoriza a aplicação do artigo 221 da Lei das S.A. no caso de transformação de sociedade limitada em companhia ao dispor que o ato de transformação obedecerá aos preceitos reguladores do tipo em que vai converter-se, motivo pelo qual a renúncia prevista em seu parágrafo único será válida.

\subsection{Não abertura do capital de sociedade resultante de operação}

Segundo o art. 223 da Lei das S.A., a incorporação, fusão ou cisão podem ser operadas entre sociedades de tipos iguais ou diferentes. Se a incorporação, fusão ou cisão envolverem companhia aberta, as sociedades que a sucederem serão também abertas, devendo obter o respectivo registro e, se for o caso, promover a admissão de negociação das novas ações no mercado secundário, no prazo máximo de 120 (cento e vinte) dias, contados da data da assembleia geral que aprovou a operação $\left(\S 3^{\circ}\right)$. 
No caso de haver descumprimento do previsto acima, será conferido ao acionista o direito de retirar-se da companhia, mediante reembolso do valor de suas ações (art. 223, $\S 4^{\circ}$ da Lei das S.A.).

O fundamento da hipótese em questão é que "a substituição das ações da companhia aberta por ações de companhia fechada constitui mudança importante na companhia emissora, devido à perda de liquidez das ações". Por tal razão, o acionista acaba sendo prejudicado pela alteração societária, possuindo menores recursos negociais, motivo pelo qual lhe é conferido o direito de retirar-se da sociedade mediante o reembolso das ações.

\subsection{Aquisição de controle por desapropriação}

Sempre que pessoa jurídica de direito público adquirir, por desapropriação, o controle de companhia em funcionamento, os acionistas terão direito de pedir o reembolso das suas ações, salvo se a companhia já se achava sob o controle, direto ou indireto, de outra pessoa jurídica de direito público, ou no caso de concessionária de serviço público (art. 236, par. Único, lei 6.404/76).

Na desapropriação de ações, a pessoa jurídica de direito público expropria para si o controle de uma companhia de direito privado, transformando-a em uma sociedade de economia mista. Neste caso, pode ocorrer a expropriação de todas ou de apenas algumas ações da companhia, de modo que o direito de recesso existe apenas quando as ações desapropriadas asseguram o controle da companhia.

A lei determina apenas duas excludentes ao direito de recesso nesta hipótese: (i) quando a companhia já se achava sob o controle, direto ou indireto, de outra pessoa jurídica de direito público; ou (ii) quando a companhia é concessionária de serviços públicos. 
Acerca do tema, Luis Eduardo Bulhões Pedreira acrescenta, citando Caio Tácito $\left(1984\right.$, p. 49) ${ }^{42}$ :

A sociedade de economia mista sofre, em suma, de uma crise dialética, uma intrínseca contradição de dever de serviço público, e o acionista privado, que persegue o estrito resultado de um investimento financeiro. Daí por que a desapropriação de ações que leva à aquisição compulsória do controle por parte do expropriante desqualifica os objetivos ordinários da companhia e quebra a unidade de interesses entre os sócios, privilegiando o interesse público, que passa a dominar a política e a estratégia da sociedade.

Assim, com a mudança no bloco de controle, há uma mudança fundamental na política a ser adotada para a gerência da companhia, de modo que a lei busca assegurar ao acionista minoritário a possibilidade de deixar de ser acionista de uma companhia completamente diversa daquela na qual escolheu investir.

Neste caso, os acionistas terão direito de pedir, dentro de 60 (sessenta) dias da publicação da primeira ata da assembleia geral realizada após a aquisição do controle, o reembolso das suas ações.

\subsection{Incorporação de ações}

A incorporação de ações consiste em operação por meio da qual uma companhia adquire todas as ações de outra sociedade por ações, tornando-a sua subsidiária integral.

A conversão de uma companhia em subsidiária integral, através da incorporação das ações de uma no patrimônio da outra, consiste em um aumento de capital da sociedade controladora (incorporadora). Isto porque, através da incorporação das ações, haverá uma transferência à sociedade incorporadora das ações detidas pelos acionistas da incorporada, que, como forma de pagamento,

\footnotetext{
${ }^{42}$ PEDREIRA, L. E. Op. Cit., p. 261.
} 
não receberão dinheiro, mas ações decorrentes do aumento de capital, que deve ser previamente deliberado e aceito por todos os acionistas da incorporadora.

De acordo com o art. 252, $\S 1^{\circ}$ da Lei das S.A., os acionistas da companhia incorporadora não terão direito de preferência para subscrever o aumento de capital.

Como consequência, será garantido aos acionistas dissidentes da assembleia geral que aprovar a operação e autorizar o aumento de capital o direito de retirar-se da companhia, devendo ser observado o disposto no art. 137, II da Lei 6.404/76, ou seja, a ausência de liquidez e dispersão das ações.

No mesmo sentido, também é assegurado o direito de retirada aos acionistas dissidentes da incorporada, na deliberação da assembleia que aprovar a operação, conforme dispõe o $\S 2^{\circ}$ do art. 252 da mesma lei.

\subsection{Aquisição do controle de outra sociedade empresária}

Segundo o art. 256 da Lei das S.A., a compra, por companhia aberta, do controle de qualquer sociedade empresária, dependerá de deliberação da assembleia geral da compradora, especialmente convocada para conhecer da operação, sempre que:

a. $\mathrm{O}$ preço de compra constituir, para a compradora, investimento relevante; ou

b. O preço médio de cada ação ou quota ultrapassar uma vez e meia o maior dos 3 (três) valores a seguir indicados: i) cotação média das ações em bolsa ou no mercado de balcão organizado, durante os noventa dias anteriores à

data da contratação; ii) valor de patrimônio líquido da ação ou quota, avaliado o patrimônio a preços de mercado; iii) valor do lucro líquido da ação ou quota, que 
não poderá ser superior a 15 (quinze) vezes o lucro líquido anual por ação nos 2 (dois) últimos exercícios sociais, atualizados monetariamente.

Segundo o parágrafo $2^{\circ}$ do mesmo artigo, se o preço da aquisição ultrapassar uma vez e meia o maior dos três valores acima mencionados, o acionista dissidente da deliberação da assembleia que a aprovar terá o direito de retirar-se da companhia mediante o reembolso do valor de suas ações, nos termos do art. 137, observado o disposto no inciso II. Desta forma, a restrição quanto à ausência de liquidez e dispersão, para que seja possível o exercício do direito de retirada, também se aplica à tal hipótese.

Nas palavras do professor Nelson Eizirik ${ }^{43}$ : "em tal caso, presume-se que o preço pago é excessivo, não sendo necessário que o acionista dissidente demonstre que a operação é danosa".

Trata-se de hipótese de exercício do direito de retirada essencialmente diversa das demais, uma vez que decorre de deliberação da assembleia geral que não implica modificação nas bases essenciais da companhia.

Implica, no entanto, em um potencial dano patrimonial aos acionistas, de modo que a norma tem como objetivo garantir àqueles que não costumam participar da administração da companhia o conhecimento das condições da operação e suas implicações na companhia, assegurando a possibilidade de fiscalizar os atos dos administradores e do acionista controlador.

\subsection{Inserção no estatuto de convenção de arbitragem}

A Lei $\mathrm{n}^{\circ} 13.129 / 2015$, elaborada a fim de atualizar a Lei de Arbitragem e ampliar o âmbito de aplicação de tal instituto, acrescentou o art. 136-A à Lei 6.404/76, dispondo sobre nova hipótese de exercício do direito de recesso.

\footnotetext{
${ }^{43}$ EIZIRIK, Nelson. Op. Cit., p. 227.
} 
Trata-se da previsão que determina que a aprovação da inserção de convenção de arbitragem no estatuto social obriga a todos os acionistas, sendo assegurado aos acionistas dissidentes o direito de retirar-se da companhia mediante o reembolso do valor de suas ações, nos termos do art. 45 da Lei das S.A.

A Lei excepciona, no entanto, o direito previsto em tal artigo, em duas situações:

a. Caso a inclusão da convenção de arbitragem represente condição para que os valores mobiliários de emissão da companhia sejam admitidos à negociação em segmento de listagem de bolsa de valores ou de mercado de balcão organizado que exija dispersão acionária mínima de $25 \%$ (vinte e cinco por cento) das ações de cada espécie ou classe;

b. Caso a inclusão da convenção de arbitragem seja efetuada no estatuto social de companhia aberta cujas ações sejam dotadas de liquidez e dispersão no mercado, nos termos das alíneas "a" e "b" do inciso II do artigo 137 da mesma Lei. 


\section{CAPÍTULO 5 - O REEMBOLSO}

O reembolso é a operação por meio da qual, nos casos previstos em lei, a companhia paga, aos acionistas dissidentes de determinada deliberação assemblear, o equivalente ao valor de suas ações (art. 45 da lei 6.404/76). Ou seja, consiste em uma recompra compulsória pela companhia de ações de sua emissão, na medida em que não pode contestar o exercício do direito pelos acionistas, nas hipóteses cabíveis.

O parágrafo primeiro do artigo supramencionado previa, originalmente, que: "O estatuto poderá estabelecer normas para determinação do valor de reembolso, que em qualquer caso, não será inferior ao valor de patrimônio líquido das ações, de acordo com o último balanço aprovado pela assembleia geral."

O valor do patrimônio líquido por ação é o resultado da divisão do valor do patrimônio líquido da companhia pelo número de ações, obtido através do Balanço Patrimonial.

O patrimônio líquido da companhia, por sua vez, pode ser entendido, de forma simplificada, como a soma algébrica do valor contábil dos ativos e passivos de uma entidade.

Assim, de acordo com a redação original, ao acionista dissidente era assegurado o direito de nunca receber, pelo exercício do direito de retirada, quantia inferior ao valor patrimonial de suas ações.

Com o advento da lei $\mathrm{n}^{\circ}$ 9.457/97 o texto do artigo em referência foi substancialmente alterado, tendo sido nele introduzido o critério de avaliação chamado de valor econômico. A nova redação do parágrafo primeiro do artigo 45 da Lei prevê o seguinte: 
O estatuto pode estabelecer normas para a determinação do valor de reembolso, que, entretanto, somente poderá ser inferior ao valor de patrimônio líquido constante do último balanço aprovado pela assembleia geral, observado o disposto no $\S 2^{\circ}$, se estipulado com base no valor econômico da companhia, a ser apurado em avaliação $\left(\S \S 3^{\circ}\right.$ e $\left.4^{\circ}\right)$.

\section{A respeito da alteração legislativa, ensina o professor Francisco} Müssnich $^{44}$ :

A adoção do critério do valor econômico para pagamento aos acionistas dissidentes nada mais é do que a permissão para que a companhia pague ao acionista, em caso de retirada, o seu verdadeiro valor, apurado por uma empresa especializada ou por três peritos.

$[\ldots]$

O critério econômico também pode ser percebido como o mais adequado simplesmente por ser absolutamente costumeiro, pois que no momento de se adquirir as ações de uma companhia, o critério patrimonial jamais é utilizado. O preço de compra é sempre correspondente ao valor econômico, ou ao valor de mercado da ação, sendo o valor patrimonial absolutamente ineficaz para esta finalidade.

Neste tocante, é importante notar que o critério de avaliação pelo valor econômico comporta diversos tipos de metodologias a serem escolhidos pela companhia, tais como a regra do Fluxo de Caixa Descontado e a regra dos Múltiplos (Avaliação Relativa/ Comparação Direta).

O primeiro e mais comum, consiste em uma projeção daquilo que a empresa poderá produzir no futuro, descontado o tempo que levará até o evento futuro acontecer e os riscos assumidos. Conforme explica Miguel Antonio Bahury Junior $^{45}$ :

Esta metodologia estima o valor de uma empresa como sendo o valor presente dos fluxos de caixa das operações projetados, assim considerados os ingressos e desembolsos (inclusive investimentos necessários à manutenção e à expansão das atividades) previsíveis sob a perspectiva de perpetuidade da empresa.

\footnotetext{
${ }^{44}$ MÜSSNICH, Francisco Antunes Maciel. Op. Cit., p. 288.

${ }^{45}$ BAHURY JUNIOR, Miguel Antonio. Laudos de Avaliação: instrução CVM no 361/2002. Rio de Janeiro: Universidade Federal do Rio de Janeiro, 2005, p. 11.
} 
Por outro lado, para calcular o valor econômico de uma companhia utilizando a metodologia de Múltiplos de Mercado, realiza-se uma análise comparativa do desempenho econômico-financeiro de companhias com características semelhantes no mercado.

A este respeito, afirma Miguel Antonio Bahury Junior, citando Damodaran ${ }^{46}$ :

$\mathrm{Na}$ Avaliação por múltiplos, também conhecida como Avaliação relativa ou Comparação direta, o valor de um ativo deriva da precificação de ativos comparáveis, padronizados pelo uso de uma variável comum, como lucros, fluxos de caixas, receitas, despesas etc.

Sendo assim, a alteração do artigo em comento não importou, necessariamente, na presunção de um critério valorativo que tenha resultado inferior ao valor do patrimônio líquido da companhia, pois o valor econômico poderá, em certas situações, superar aquele do patrimônio líquido.

É incontestável, no entanto, que a nova redação confere maior liberdade à empresa para escolher a metodologia que melhor se aplica à sua realidade econômica, de modo a mitigar os impactos financeiros decorrentes do pagamento do reembolso.

A este respeito, disserta o professor Modesto Carvalhosa ${ }^{47}$ :

Têm ocorrido algumas arguições no sentido de que a adoção substitutiva estatutária do valor econômico prejudicaria o acionista que não soubesse, no momento de exercer o recesso, o valor do reembolso respectivo. Daí a eventual inibição do exercício desse direito. Por outro lado, a imposição desse critério impediria o oportuno direito de retratação da companhia (art. $137, \S 3^{\circ}$ ). Com referência à companhia, a objeção não prevalece, pois a administração, ao propor a alteração estatutária, deverá já ter em conta, previamente, o impacto que a medida proposta eventualmente tenha no valor econômico da companhia. Por outro lado, o prazo de dez dias mantido pela lei de 1997, após o término do exercício eficaz dos dissidentes, é suficiente, em face dos dados de valor econômico presumivelmente já possuídos pela administração, para que a

\footnotetext{
${ }^{46}$ BAHURY JUNIOR, Miguel Antonio. Op. Cit.

${ }^{47}$ CARVALHOSA, Modesto. Comentários à lei de sociedades anônimas: Lei ${ }^{\circ}$ 6.404, de 15 de dezembro de 1976, com as modificações das Leis $n^{\circ}$ 9.457, de 5 de maio de 1997 e 10.303, de 31 de outubro de 2001. São Paulo: Saraiva, 2002, p. 431.
} 
assembleia geral delibere pela retratação. A hipótese, ademais, não foi cogitada pelo legislador de 1997 que, ao manter o prazo de dez dias, pressupôs que o valor econômico será sempre muito menor do que o do patrimônio líquido. Daí esperar-se que a dissidência receba valor muito inferior ao do patrimônio líquido e, portanto, capaz de ser suportado pela companhia.

No que diz respeito à alegação de que a incerteza quanto ao valor econômico poderia inibir o exercício do direito de recesso pelos acionistas minoritários, aduz o supracitado autor que esta teria sido a exata intenção do legislador.

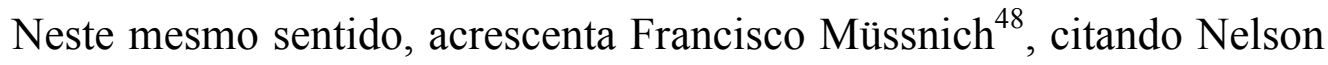
Eizirik:

Como o valor do patrimônio líquido é, o mais das vezes, bastante superior ao valor econômico ou ao valor de Bolsa, tal dispositivo constituía um incentivo à 'indústria do recesso', onerando eventuais operações legítimas da companhia, porém ensejadoras do direito de recesso.

Com a nova redação dada ao $\S 1^{\circ}$ do art. 45 , admite-se que o estatuto estipule o preço de reembolso com base no valor econômico da companhia, apurado em avaliação, nos termos dos $\S \S 3^{\circ}$ e $4^{\circ}$ do mesmo artigo.

O valor econômico corresponde à perspectiva de rentabilidade da companhia, ou seja, ao seu fluxo de caixa descontado, nos próximos anos. Trata-se de uma avaliação 'dinâmica' da companhia, enquanto atividade empresarial, em contraposição à avaliação 'estática', centrada no valor patrimonial.

A sugestão de tal critério de avaliação pelo legislador derivaria do entendimento de que o fluxo de caixa descontado representa o critério fundamental para fins de verificação do valor de mercado de uma companhia. A capacidade de fluxo de caixa demonstra o quanto a companhia é saudável e rentável, através do qual se extrai o laudo sobre o seu valor econômico.

A este respeito, ensina Luis Eduardo Bulhões Pedreira ${ }^{49}$ :

\footnotetext{
${ }^{48}$ EIZIRIK, Nelson. Comentando a Lei n ${ }^{\circ}$ 9.457/97 apud MÜSSNICH, Francisco Antunes Maciel. Op. Cit., p. 288.

${ }^{49}$ PEDREIRA, L. E. Op. Cit., p. 277.
} 
A LSA não define 'valor econômico da companhia', mas, por analogia ao disposto no $\S 1^{\circ}$ do artigo 170 (que trata de aumento de capital mediante subscrição de ações), o valor econômico da companhia (e da ação) deve ser determinado com base nos seguintes critérios, aplicados alternativa ou conjuntamente: (a) perspectiva de rentabilidade da companhia, inclusive valor presente (descontado) do fluxo de renda futuro (esperado) da companhia que couber à ação; (b) valor de patrimônio líquido da ação, que pode ser o contábil ou avaliados os bens a preços de mercado; e (c) valor de troca no mercado de valores mobiliários.

Quando a rentabilidade da companhia é muito baixa, ou até mesmo negativa, seu valor econômico será inferior ao patrimônio líquido, pois o valor de liquidação será inferior ao contábil. Por outro lado, quando a rentabilidade é alta, o valor econômico tende a ser superior ao valor do patrimônio líquido.

Não havendo expressa disposição estatutária prevendo a adoção do critério do valor econômico, prevalece a regra geral que determina o cálculo do reembolso tendo por base o valor do patrimônio líquido contábil da ação demonstrado no último balanço aprovado pela companhia.

Contudo, o artigo 264 da Lei 6.404/76 excepciona a regra acima descrita, ao oferecer uma proteção adicional aos acionistas minoritários na hipótese de operações de incorporação, fusão e incorporação de ações envolvendo sociedades controladas, controladoras ou sob controle comum.

Nestes casos, a lei determina que seja elaborada uma avaliação especial das companhias envolvidas na operação, com base no critério do patrimônio líquido a preços de mercado ou outro critério expressamente aceito pela Comissão de Valores Mobiliários (CVM). A avaliação serve como base para fins de comparação com o critério anteriormente escolhido pelos administradores e controladores da companhia, indicado no protocolo e justificação da operação, de maneira que os acionistas tenham a possibilidade de verificar se a escolha de tal critério foi justa.

A partir desta verificação, os acionistas dissidentes possuem a opção de escolher entre receber o valor de reembolso decorrente da regra geral, indicada 
no artigo 45 da Lei das S.A., ou o valor resultante da avaliação feita com base no artigo 264 da mesma lei.

Além disso, caso a deliberação da assembleia geral que motivar o exercício do direito de recesso ocorra 61 dias depois da data do último balanço aprovado, o acionista dissidente poderá requerer, juntamente com o reembolso, o levantamento de um balanço especial em data que atenda àquele prazo.

Nesse caso, a companhia pagará imediatamente $80 \%$ do valor de reembolso calculado com base no último balanço e, levantado o balanço especial, pagará o saldo no prazo de 120 dias a contar da data da deliberação da assembleia (artigo 45, $\S 2^{\circ}$ da Lei). Caso seja constatado, posteriormente, que o valor recebido antecipadamente pelo acionista constitui valor superior ao devido efetivamente, este deverá devolver a diferença à companhia.

Quanto ao fundamento da regra supracitada, aduz Nelson Eizirik ${ }^{50}$ :

Tal regra visa a possibilitar que o valor de reembolso retrate, com mais fidelidade, a situação patrimonial da companhia no momento em que o acionista exerce o direito de recesso, de forma que ele possa abranger, por exemplo, eventuais lucros aferidos pela companhia entre a data do último balanço aprovado pela assembleia geral e a data em que for deliberada a operação ensejadora do direito de retirada.

O pagamento do valor do reembolso passa a ser exigível após 10 dias da data em que termina o prazo em que pode ser reclamado pelos acionistas dissidentes. Durante este período, a companhia tem a faculdade de convocar uma nova assembleia para reconsiderar ou ratificar a deliberação que deu origem ao direito de recesso, caso entenda que o pagamento do preço do reembolso poderá colocar em risco a estabilidade financeira da companhia.

Vale ressaltar, contudo, que os parágrafos $7^{\circ}$ e $8^{\circ}$ do artigo 45 da Lei 6.404/76 estabelecem que, ocorrendo a falência da companhia, os acionistas

\footnotetext{
${ }^{50}$ EIZIRIK, Nelson. A Lei das S/A Comentada. vol. I. arts. $1^{\circ}$ a 120. São Paulo: Quartier Latin, 2011, p. 297.
} 
dissidentes somente poderão ser reembolsados após o pagamento integral dos credores da massa falida. Assim, os dissidentes serão considerados credores quirografários, e as quantias devidas aos credores mais antigos não serão deduzidas dos créditos dos ex-acionistas, que serão satisfeitos integralmente pelos bens da massa falida, após o pagamento integral dos demais credores.

Acerca da vigência da regra acima descrita, explica Nelson Eizirik ${ }^{51}$ :

No entanto, a Lei de Recuperação e Falência de Empresas - Lei n ${ }^{\circ}$ 11.101/2005 classificou como créditos subordinados "os créditos dos sócios e dos administradores sem vínculo empregatício",757. Assim, o crédito, pelo valor de reembolso, do acionista dissidente é considerado subordinado e, portanto, será pago posteriormente aos créditos quirografários da massa falida. Dessa forma, o $\S 7^{\circ}$ foi derrogado pelo artigo 83 da Lei $n^{0} 11.101 / 2005^{758}$. Note-se que essa mesma lei determina, expressamente, que a decretação da falência suspende o exercício do direito de retirada ou de recebimento do valor de reembolso por parte dos acionistas da companhia falida.

Caso a falência ocorra após o pagamento do reembolso dos ex-acionistas, à conta do capital social, e novos acionistas não tiverem substituído tal valor, e a massa não bastar para o pagamento dos créditos mais antigos, caberá ação revocatória para restituição do reembolso pago com redução do capital social, até a ocorrência do que remanescer desta parte do passivo. A restituição ocorrerá na mesma proporção de todos os acionistas cujas ações tenham sido reembolsadas (Art. 45, $\S 8^{\circ}$ da Lei das S.A.).

Além disso, com relação à alteração estatutária que determina a adoção do critério econômico para fins de aferição do valor de reembolso, o supracitado autor acrescenta ${ }^{52}$ :

No entanto, a companhia não poderá, no prazo de 1 (um) ano, após a referida alteração estatutária, aprovar operação que enseje o direito de recesso sendo o valor de reembolso menor ao que teriam direito os acionistas dissidentes se considerado o critério anterior, sob pena de ser caracterizado o exercício abusivo do poder de controle e infração grave nos termos do artigo $11, \S 3^{\circ}$, da Lei $n^{\circ} 6.385 / 1976$.

\footnotetext{
${ }^{51}$ Id., p. 302.

${ }^{52}$ Id., p. 296.
} 
Por fim, há de se destacar que a mencionada alteração estatutária não enseja o exercício do direito de recesso, posto que tais hipóteses são taxativamente previstas em lei e não abrangem a referida situação. 


\section{CAPÍTULO 6 - CONSEQUÊNCIAS DO EXERCÍCIO DO DIREITO DE RETIRADA}

No artigo 137, inciso I da Lei das S.A., é disposto que, nos casos dos incisos I e II do artigo 136, somente terá direito de retirada o titular de ações de espécie ou classe prejudicadas.

Ou seja, nas hipóteses de criação de ações preferenciais ou aumento desproporcional de classe de ações preferenciais existentes; e de alteração nas preferências, vantagens e condições de resgate ou amortização de uma ou mais classes de ações preferenciais, ou criação de nova classe mais favorecida, somente terão direito de retirada os acionistas prejudicados.

Contudo, tendo em vista todo o histórico apresentado acerca do direito de retirada, o fundamento de sua criação, bem como as hipóteses que o ensejam, é possível perceber que o inciso ora mencionado não tem como escopo limitar a necessidade de prejuízo a apenas tais hipóteses para que haja direito de recesso, mas sim limitá-lo, naquelas hipóteses, aos acionistas prejudicados.

Após a análise dos casos que ensejam o direito de retirada, fica claro que o fundamento para seu exercício é um prejuízo ao acionista dissidente, ainda que tal elemento não esteja expressamente mencionado nos dispositivos estudados.

Isto porque o direito de recesso surge como remédio para que o acionista dissidente não seja obrigado a submeter-se às decisões da maioria em casos nos quais haverá uma mudança profunda nas bases do investimento feito. Neste sentido, presume o legislador que aquela mudança tem o potencial de influenciar de forma prejudicial os investimentos daquele acionista, motivo pelo qual entende não ser justo que seja obrigado a arcar com tais riscos e lhe faculta retirar-se da companhia mediante o reembolso de suas ações. 
Por outro lado, a autonomia das companhias em relação aos seus acionistas, concentrando o capital aportado por eles e destinando-o à atividade empresarial, em busca de um objetivo comum, tornou tal modelo societário um dos mais importantes instrumentos econômicos da atualidade.

Neste ponto, importa notar que tanto a legislação societária (Lei das S.A.) como a Constituição Federal reconhecem a importância da livre iniciativa para a ordem econômica brasileira, de modo que é importante interpretar o artigo 137 da Lei 6.404/76 tendo como foco não apenas os direitos acionários que pretende assegurar, mas também a importância da preservação das companhias na ordem econômica brasileira.

Por tal razão, tendo em vista o impacto que a decisão de exercer o direito de recesso pode acarretar à companhia, ao ponto de inviabilizar uma operação societária que seria importante para sua manutenção ou desenvolvimento, é evidente que tanto o critério do prejuízo, quanto a ausência de liquidez e dispersão das ações, devem ser aplicados a todas as hipóteses previstas no artigo 137 da Lei das S.A., sob pena de transformar o instituto do recesso em instrumento de abuso utilizado pelos acionistas apenas para auferirem lucros às custas companhia.

Neste ponto, explica Fábio Konder Comparato acerca do abuso no direito de recesso ${ }^{53}$ :

Não é pelo fato e os direitos essenciais do acionista serem atribuídos pela lei em defesa de interesses próprios do seu titular que deixará de existir a possibilidade jurídica de abuso. Ele ocorre, justamente, quando o interesse visado pelo agente não coincide com o que a norma estabeleceu como razão de ser da prerrogativa.

Neste sentido, a reestruturação societária e de governança corporativa da Vale S.A. pode ser utilizada como exemplo, uma vez que, no Anexo II do

\footnotetext{
${ }^{53}$ COMPARATO, Fabio Konder. Direito de Recesso de Acionista de Sociedade Anônima. Revista dos Tribunais, São Paulo, a. 71, v. 558, abr., 1982, p. 39.
} 
Manual para Participação na assembleia geral extraordinária da Vale S.A. de 27 de junho de 2017, consta a Proposta Apresentada para a Operação ${ }^{54}$, na qual foi disposto:

Os acionistas se comprometem a tomar todas as providências que se fizerem necessárias para a listagem efetiva da Vale no Novo Mercado da BM\&FBOVESPA, tão logo seja possível, desde que não haja risco material de exercício do direito de retirada por qualquer acionista detentor de ações preferenciais classe A da Vale, conforme a relação do preço de mercado das ações e seu valor patrimonial. (grifo nosso)

Neste caso, os acionistas da companhia decidiram que a reestruturação deveria ocorrer em momento no qual o preço de mercado das ações estivesse mais alto que o seu valor patrimonial, como forma de garantir que não houvesse risco de exercício ao direito de retirada, pois os acionistas dissidentes que desejassem se retirar da companhia escolheriam vendê-las ao mercado, ao invés de impor o reembolso à companhia.

Isto porque a decisão de se retirar ou não da companhia costuma ser puramente patrimonial, e raramente estratégica. O acionista, ao decidir pela permanência ou retirada na companhia, tende a avaliar o valor a ser auferido com o reembolso, e não o impacto da deliberação sobre a companhia e suas ações.

Assim, é necessário que o prejuízo seja considerado como premissa para o exercício do direito de retirada, de modo que o elemento deve ser utilizado para limitar a utilização do instituto ao seu real propósito, qual seja, proteger os acionistas minoritários de decisões majoritárias capazes de lhe causar algum dano.

A este respeito, explica o professor Francisco Müssnich ${ }^{55}$ :

\footnotetext{
${ }^{54}$ Manual para Participação da Assembleia Geral Extraordinária da Vale S.A. Bovespa. Disponível em: $<\mathrm{http}$ ://siteempresas.bovespa.com.br/consbov/ArquivoComCabecalho.asp? motivo $=\&$ protocolo $=56668$ $8 \&$ funcao $=$ visualizar $\&$ Site $=$ C $>$ Acesso em: 15 abr. 2019.

${ }^{55}$ MÜSSNICH, Francisco Antunes Maciel. Op. Cit., p. 296.
} 
É importante ressaltar que esse prejuízo não configura um dano injusto, ou seja, um dano reparável com base nos princípios da responsabilidade civil. Configura, sim, uma mera lesão aos interesses dos minoritários - a qual deve restar demonstrada - que se compõe única e exclusivamente através do pagamento ao acionista dissidente do valor do reembolso de suas ações; não há, pois, que se falar em violação aos direitos do acionista dissidente e muito menos na existência de qualquer ato ilícito.

Nem poderia ser diferente, já que o princípio majoritário é o princípio que governa em geral a vida das companhias. Por esta razão, deve o direito de recesso ser encarado apenas como uma possibilidade de saída do acionista dissidente em decorrência de determinadas deliberações extremamente importantes à vida societária, e nunca como um meio de o acionista ser indenizado por qualquer dano que porventura determinada deliberação tenha lhe causado.

Os interesses da companhia são os legítimos interesses que devem sempre ser almejados e não os interesses egoístas de cada acionista. Assim, a tendência mundial é a de reduzir cada vez mais as matérias sujeitas ao recesso.

Acrescenta o mesmo autor, citando Arnoldo Wald ${ }^{56}$ :

Em síntese, a visão panorâmica do direito comparado nos leva à conclusão de que a evolução que se realiza é no sentido de, reconhecendo-se a natureza institucional da sociedade anônima aberta e a viabilidade da venda das ações em bolsa, só se admitir o recesso excepcionalmente nos casos de fusão e incorporação, de transformação ou de mudança do objeto social, nos casos em que as ações não são negociadas em bolsa ou quando há evidente abuso de maioria, ensejando um prejuízo aos minoritários em detrimento do interesse social.

Assim, tendo em vista o entendimento doutrinário no sentido de que as causas do recesso devem ser a exceção, bem como seu impacto nas deliberações da companhia e sua tendência, no direito comparado, no sentido de reduzir cada vez mais as causas que o ensejam, fica evidente que o prejuízo deve ser utilizado como requisito para o exercício deste direito, limitando-o à razão para o qual foi criado, ou seja, para a proteção do acionista minoritário, e não como instrumento para obtenção de ganho patrimonial indevido.

Assim, ficam assegurados os interesses da companhia através das alterações que lhe são necessárias e, ao mesmo tempo, ao acionista dissidente é assegurado o exercício do direito de recesso, quando a deliberação for capaz de lhe causar prejuízos.

\footnotetext{
${ }^{56}$ WALD, Arnoldo apud MÜSSNICH, Francisco Antunes Maciel. Op. Cit., p. 296.
} 


\section{CONSIDERAÇÕES FINAIS}

Com o advento das sociedades por ações, tipo societário que melhor se destina à concentração de capitais e que possui, como uma de suas características principais, a fungibilidade de seus membros, surgiu a necessidade de criação de instrumento capaz de viabilizar a consecução das atividades empresariais sem que fosse necessário o consentimento unânime dos sócios da companhia, que viria a ser chamado, posteriormente, de princípio majoritário.

No entanto, tendo em vista o poder investido à maioria, através do princípio majoritário, para deliberar sobre o futuro da companhia, percebeu-se, com o tempo, a necessidade de criação de um instituto capaz de contrabalançar o poder majoritário nas deliberações assembleares.

Neste contexto, as legislações de diversos Estados buscaram assegurar aos acionistas, considerados individualmente, os chamados direitos essenciais, os quais não poderiam ser modificados pelo estatuto social ou assembleia geral.

Dentre os direitos assegurados como essenciais, encontra-se o direito de recesso, com o propósito de manter o equilíbrio entre o poder atribuído à maioria de modificar as bases essenciais do contrato, e a preservação dos interesses dos minoritários.

Ao longo do tempo, entretanto, a prática demonstrou que o instituto, criado como forma de proteção aos acionistas minoritários, passou a ser, muitas vezes, utilizado como instrumento para obtenção de ganho patrimonial indevido.

Neste sentido, ao analisar deliberações capazes de ensejar o direito de retirada, o acionista passou a avaliar tão somente o ganho a ser auferido com o reembolso de suas ações, de forma a não considerar o interesse da companhia e a necessidade de modificação para melhor realizar seu objeto social. 
Como consequência, muitas vezes a companhia é obrigada a retratar-se acerca da deliberação, deixando de realizar a alteração que entendia ser necessária, devido ao grande número de acionistas dissidentes que manifestaram a intenção de exercer o direito de retirada, pois o pagamento do reembolso seria extremamente oneroso para a sociedade.

Por tal razão, as diversas alterações normativas no instituto demonstraram a incerteza legislativa quanto à sua melhor aplicação, ora enfraquecendo, ora fortalecendo o exercício deste direito.

A redação atual busca fortalecer o instituto na medida em que amplia as hipóteses que ensejam o exercício do direito de recesso. Reconhece, contudo, o impacto do pagamento do reembolso sobre as finanças da companhia, de modo que cria requisitos a serem preenchidos pelo acionista dissidente para que tenha direito ao exercício do recesso.

Assim, o legislador determina que apenas os acionistas prejudicados poderão retirar-se da sociedade nas hipóteses de criação de ações preferenciais ou aumento desproporcional de classe de ações preferenciais existentes; e de alteração nas preferências, vantagens e condições de resgate ou amortização de uma ou mais classes de ações preferenciais, ou criação de nova classe mais favorecida.

Além disso, determina que nos casos de fusão, incorporação e participação em grupo de sociedades, não terá direito de retirada o titular de ação de espécie ou classe que tenha liquidez e dispersão no mercado.

Ocorre que os requisitos mencionados deveriam aplicar-se a todas as hipóteses de ensejo do exercício do direito de retirada, posto que limitar-se aos casos acima citados propicia o abuso na utilização do instituto desviando-se da razão pela qual foi tutelado. 
É importante que estejam presentes em todas as hipóteses de exercício do direito de retirada a ausência dos elementos de liquidez e dispersão das ações, pois a existência destes deixa clara a possibilidade do acionista negociar suas ações no mercado, de forma que não será obrigado a permanecer em companhia diversa daquela na qual investiu originariamente, e a companhia não será obrigada ao pagamento de valor que poderia ser investido no exercício de suas atividades.

Ainda, é necessário que haja o elemento prejuízo presente nos casos em que haverá o exercício do direito de recesso, haja visto que o instituto foi criado como uma forma de assegurar ao acionista dissidente o direito de retirar-se da companhia nos casos em que a deliberação majoritária pode afetar de maneira profunda o investimento feito, de modo a prejudicar sua posição acionária.

Fica claro, portanto, que a limitação do direito de recesso através da aplicação de tais premissas é de extrema importância para evitar o abuso dos acionistas em casos que ensejam o direito de retirada, impedindo a utilização do instituto como instrumento para auferir lucros, prejudicando o desenvolvimento da atividade empresarial. 


\section{REFERÊNCIAS BIBLIOGRÁFICAS}

BAHURY JUNIOR, Miguel Antonio. Laudos de Avaliação: instrução CVM $n^{\circ}$ 361/2002. Rio de Janeiro: Universidade Federal do Rio de Janeiro, 2005.

BORBA, José Edwaldo Tavares. Direito societário. 13.ed. Rio de Janeiro: Renovar, 2012.

CARVALHOSA, Modesto. Comentários à Lei de Sociedades Anônimas. vol. II. arts. 75 a 137. 5. ed. São Paulo: Saraiva, 2011.

. Comentários à lei de sociedades anônimas: Lei $n^{0} 6.404$, de 15 de dezembro de 1976, com as modificações das Leis $\mathrm{n}^{\circ}$ 9.457, de 5 de maio de 1997 e 10.303, de 31 de outubro de 2001. São Paulo: Saraiva, 2002.

CODICE CIVILE ITALIANO. Disponível em:

$<$ http://www.jus.unitn.it/cardozo/obiter_dictum/codciv/Lib5.htm> Acesso em: 15 abr. 2019.

CODICE DI COMMERCIO DEL REGNO D'ITALIA. Roma: Regia Tipografia, 1882. Disponível em:

$<$ http://www.antropologiagiuridica.it/codecomit82.pdf $>$ Acesso em: 05 abr, 2019.

COMPARATO, Fabio Konder. Direito de Recesso de Acionista de Sociedade Anônima. Revista dos Tribunais, São Paulo, a. 71, v. 558, abr., 1982.

EIZIRIK, Nelson. A Lei das S/A Comentada. vol. I. arts. $1^{\circ}$ a 120. São Paulo: Quartier Latin, 2011.

. A Lei das S/A Comentada. vol. II. arts. 121 a 188. São Paulo:

Quartier Latin, 2011.

LAMY FILHO, Alfredo; PEDREIRA, José Luiz Bulhões. A Lei das S.A.: pareceres. 3. ed. Rio de Janeiro, Renovar, 1997.

. A Lei das S.A.: pressupostos, elaboração, aplicação. Rio de Janeiro: Renovar, 1996. 
LOUREIRO, Antonio José da Silva. Código Mercantil da França traduzido. Rio de Janeiro: Typ. Nacional, 1825. Disponível em:

$<$ http://www2.senado.leg.br/bdsf/handle/id/242784> Acesso em: 05 abr. 2019.

Manual para Participação da Assembleia Geral Extraordinária da Vale S.A.

Bovespa. Disponível em:

$<$ http://siteempresas.bovespa.com.br/consbov/ArquivoComCabecalho.asp?mot $\mathrm{ivo}=\&$ protocolo $=566688 \&$ funcao $=$ visualizar $\&$ Site $=C>$ Acesso em: $15 \mathrm{abr}$. 2019.

MARTINS, Fran. O direito de recesso na lei brasileira das sociedades anônimas. Revista Forense, v. 1, jul./set., 1904.

MORITZ, Renata Brandão. As Hipóteses de Recesso da Lei das Sociedades Anônimas. Revista dos Tribunais, São Paulo, a. 86, v. 736, fev., 1997.

MÜSSNICH, Francisco Antunes Maciel. Reflexões sobre o direito de recesso na lei das sociedades por ações: reforma da lei das sociedades anônimas, inovações e questões controvertidas da Lei $n^{\circ} 10.303$, de 31.10.2001. 2. ed. Rio de Janeiro: Forense, 2002.

PARAISO, Anna Luiza Prisco. O Direito de Retirada do Acionista Dissidente. Revista da CVM, Rio de Janeiro, v.4, n. 12, p.17-26, abr./jun.,1986.

PEDREIRA, L.E. Direito de retirada. In: LAMY FILHO, Alfredo; PEDREIRA, José Luiz Bulhões. Direito das companhias. 2. ed. Rio de Janeiro: Forense, 2017.

PENTEADO, Mauro Rodrigues. A Lei 7.958/89 e a Pretensa Modificação do Direito de Retirada dos Acionistas: uma discussão inócua. Revista de Direito Mercantil, Industrial, Econômico e Financeiro, São Paulo, n. 77, a. 29, jan./mar., 1990.

PENTEADO, Mauro. Trattato di Diritto Commerciale. 5. ed. Milão: Vallardi, 1923.

PRACTICAL LAW. Glossary. Thomson Reuters. Disponível em: $<$ https://uk.practicallaw.thomsonreuters.com/4-382-

3234 ?transitionType $=$ Default\&contextData $=($ sc. Default $) \&$ firstPage $=$ true $\&$ com $\mathrm{p}=$ pluk\&bhcp=1>. Acesso em: 15 abr. 2019. 
STATE OF DELAWARE. The Official Website of the First State.

Disponível em: $<$ http://delcode.delaware.gov/title8/c001/sc09/index.shtml.> Acesso em: 15 abr. 2019.

SZTAJN, Rachel. O direito de recesso nas sociedades comerciais. Revista de Direito Mercantil, v.27, n.71, p. 15, 1988.

The market out exception delawares unique twist on a commonly used anti appraisal device. Appraisal rights litigation. Disponível em:

$<$ https://www.appraisalrightslitigation.com/2016/04/13/the-market-outexception-delawares-unique-twist-on-a-commonly-used-anti-appraisaldevice/> Acesso em: 15 abr. 2019. 